Primljeno: 8.6.2020.

Prihvaćeno: 19.8.2020.

DOI: $10.36506 /$ av.63.3

\author{
Dijana Cenger \\ Virovitica, Hrvatska \\ Državni arhiv u Virovitici \\ arhiv.virovitica@vt.t-com.hr
}

\title{
RELEVANTNOST VJESNIKOVE NOVINSKE DOKUMENTACIJE KAO KULTURNOGA DOBRA REPUBLIKE HRVATSKE I ARHIVSKOGA IZVORA
}

UDK: 002

025.2:070

070:001.8

070(497.5)(060.1/.9)

Izvorni znanstveni rad

$U$ radu se analizira korisnicka funkcija novinske zbirke nastale u okviru izdavačke kuće Vjesnik u razdoblju od 1964. do 2006. godine. Prezentirani su rezultati analize dostupnosti i korištenja Vjesnikove novinske dokumentacije u razdoblju od 1. lipnja 2013. godine, odnosno od njezine predaje Hrvatskomu državnomu arhivu i proglašenja kulturnim dobrom Republike Hrvatske, do 31. prosinca 2019. godine. Relevantnost Vjesnikove novinske zbirke kao arhivskoga izvora za znanstvena $i$ stručna istraživanja dodatno je istražena analizom sadržaja njezinih tematskih cjelina te ispitivanjem podudarnosti sadržaja u tehničkim jedinicama sa strukturiranim popisom, na uzorku od minimalno 1\% tehničkih jedinica. Rezultati analize prikazani su u obliku grafikona i tabličnih prikaza. Temeljem dobivenih rezultata istraživanja, pregleda mrežno dostupnih novina i časopisa s područja Socijalističke Federativne Republike Jugoslavije u razdoblju od 1964. do 1990. i s područja Republike Hrvatske u razdoblju od 1990. do 2006. godine te dosadaśnjega iskustva u pokušajima digitalizacije Vjesnikove dokumentacijske zbirke, u radu se preispituje nužnost njezine cjelovite digitalizacije te sugeriraju smjernice za daljnja postupanja $u$ vezi s povećanjem njezine dostupnosti i zaśtite.

Ključne riječi: Vjesnik; Vjesnikova novinska dokumentacija; korištenje; digitalizacija; novinska zbirka; arbivsko gradivo 


\section{Uvod: Vjesnikova novinska dokumentacija u funkciji matične informativne kuće $i$ javnoga servisa}

Vjesnikova novinska dokumentacija dokumentacijska je zbirka novinskih članaka nastala u novinsko-izdavačkom i tiskarskom poduzeću Vjesnik prikupljanjem i obradom ${ }^{1}$ novina i časopisa s područja Socijalističke Federativne Republike Jugoslavije iz razdoblja od 1964. do 1991. godine te dnevnih i tjednih novina objavljenih u Republici Hrvatskoj do 2006. godine.

U prvom desetljeću stvaranja Vjesnikove dokumentacijske zbirke Novinarsko-izdavačko i tiskarsko poduzeće Vjesnik postalo je najveća izdavačka kuća u Socijalističkoj Federativnoj Republici Jugoslaviji. Bilježilo je zamjetne financijske rezultate realizacijom složenoga izdavačkoga programa, ulaganjem u grafičku tehnologiju, stvaranjem razgranate dopisničke službe i izobrazbom djelatnika. ${ }^{2}$ Uspješno financijsko poslovanje i rukovođenje, unatoč socijalističkomu upravljanju i komunističkoj kontroli iz saveznoga državno-partijskoga centra, omogućilo je poduzeću Vjesnik zalaganje za uredničku neovisnost, slobodu govora, stvaranje institucije otvorenoga društva i informativno uključivanje zemlje u suvremena politička i gospodarska kretanja u svijetu. ${ }^{3}$ Osim uglednoga tjednika, a kasnije dnevnika Vjesnik, koji je izlazio u kontinuitetu od 1940. do 2012., izdavačka kuća Vjesnik tijekom svojega postojanja objavljivala je i druge periodičke publikacije: Ilustrirani vjesnik, Kerempuh, Rebus, Večernji list, Sportske novosti, Vjesnik u srijedu, Globus, Arena, Plavi vjesnik, Svijet, Studio, Izbor, Moto magazin, Start, Vikend, Fokus, Sam svoj majstor, Sprint, Tina, Zabavni omladinski vjesnik, Kviz, Sfinga, Erotika, Top, Danas, Mila, Auto klub, Astro magazin i Dječji klub. Uoči demokratskih promjena Socijalistička Federativna Republika Jugoslavija bila je pred gospodarskim kolapsom. ${ }^{4}$ Poduzeće Vjesnik s gotovo 6.000 zaposlenih, formalnoga imena Novinska, izdavačka, štamparska i prodajna radna organizacija Vjesnik n. sol. o. izgubilo je vodeću nakladničku poziciju u Socijalističkoj Republici Hrvatskoj, no unatoč tomu ulagalo je znatna sredstva u informatizaciju redakcijskoga sustava i distribuciju svojih izdanja. ${ }^{5}$ Stupanjem na snagu Zakona o

\footnotetext{
1 Obrada novina i časopisa u kontekstu formiranja Vjesnikove novinske dokumentacije podrazumijeva postupak ručnoga izrezivanja novinskih članaka i njihovo odlaganje u unaprijed formirane tematske cjeline kronološkim ili abecednim slijedom.

2 Usp. Božidar Novak, Hrvatsko novinarstvo u 20. stoljeću (Zagreb: Golden marketing, 2005), str. 559-564.

3 Usp. Nenad Bukvić, "Vjesnikova novinska dokumentacija," Courage connecting collections, pristupljeno 30. siječnja 2020., http://culturalopposition.eu/registry/?uri=http://courage.btk.mta.hu/courage/ individual/n14713.

4 U 1989. godini, uz niz drugih negativnih ekonomskih pokazatelja, zabilježena je hiperinflacija po stopi od 766,6\% u odnosu na prethodnu godinu. Usp. HR-HDA-2031. Vjesnik, 2.1, Vjesnikova novinska dokumentacija, novinski isječci iz Večernjega lista od 20. i 21. prosinca 1989. (kut. EFG 6).

5 Usp. Vladimir Slijepčević, "Pet posljednjih godina," u Zbornik sjećanja: Vjesnik 1940-1990, ur. Milan Bekić (Zagreb: NIŠPRO "Vjesnik", 1990), str. 221-249.
} 
izmjenama i dopunama Zakona o javnom informiranju ${ }^{6}$ 1990. godine Socijalistički savez radnog naroda Hrvatske prestao je biti osnivačem informativnih kuća i javnih glasila u Socijalističkoj Republici Hrvatskoj. Uslijedila je vlasnička pretvorba društvenih poduzeća. Složena organizacija Vjesnik podijeljena je na 12 samostalnih trgovačkih društava. Vjesnikova dokumentacijska zbirka u pretvorbenoj je razdiobi pripala trgovačkomu društvu imenovanom Vjesnik - politički dnevnik novinsko nakladničko poduzeće p. o., ${ }^{7}$ koje je nastavilo s proizvodnjom dnevnika Vjesnik u pretežito državnom vlasništvu. Zbog nagomilanih financijskih i organizacijskih problema početkom 2006. godine zaustavljeno je prikupljanje novinskih članaka i nadopunjavanje Vjesnikove novinske dokumentacije. U lipnju iste godine, potaknuti Mišljenjem Hrvatskog državnog arhiva o nužnosti osiguranja kontinuirane zaštite i dostupnosti Vjesnikove novinske dokumentacije u okviru neke od Vjesniku srodnih ustanova, članovi Odbora za medije Hrvatskoga sabora inicirali su njezino organizacijsko pripajanje Hrvatskoj izvještajnoj novinskoj agenciji i povezivanje s postojećom digitaliziranom bazom podataka EVA. ${ }^{8}$

Vjesnikova dokumentacijska zbirka prvenstveno je nastala radi potreba vlastite izdavačke kuće, u kontekstu relevantnih referencija za stvaranje novih novinskih sadržaja, no s vremenom je postala javni servis kojim su se služili novinari drugih izdavačkih i informativnih kuća i studenti novinarstva. Vjesnikova novinska dokumentacija zadržala je ulogu javnoga servisa i nakon demokratskih promjena, za čije su korištenje ostale izdavačke i informativne kuće i pojedine visokoobrazovne ustanove Društvu Vjesnik plaćale godišnju pretplatu. Iako je zbirku koristio velik broj istraživača i novinara, troškovi njezina održavanja znatno su premašivali prihode, što je dodatno ugrožavalo poslovanje gubitaškoga Društva Vjesnik. ${ }^{9} S$ druge strane, intenzivnim ulaganjem države u povećanje dostupnosti Interneta, praćenoga tehnološkim razvojem mrežnih medija, ${ }^{10}$ stvo-

\footnotetext{
6 Zakon o izmjenama i dopunama Zakona o javnom informiranju, NN 8/1990.
}

7 Godine 1993. tvrtka je registrirana pod imenom Novi vjesnik d.d. novinsko-nakladničke djelatnosti, a od 1996. godine djeluje pod imenom Vjesnik d.d. novinsko-nakladničke djelatnosti. "Izvješće o obavljenoj reviziji pretvorbe i privatizacije društvenog poduzeća Vjesnik," (Republika Hrvatska Državni ured za reviziju, 2003), pristupljeno 10. veljače 2019., http://www.revizija.hr/izvjesca/2007/revizijepretvorbe-i-privatizacije/850-vjesnik-zagreb.pdf.

8 Željko Hodonj i Lana Žaja, "Mediji i demokracija, baza podataka, dubinsko pretraživanje, izravni pristup - digitalizacija novinskog arhiva i organizacija znanja u bazu podataka," u INFuture2007: Digital information and Heritage, ur. Sanja Seljan i Hrvoje Stančić (Zagreb: Filozofski fakultet Sveučilišta u Zagrebu, 2007), str. 229.

9 Naplata korištenja dokumentacije - kako kome, novinski isječak iz Novog lista od 10. kolovoza 1997., HR-HDA-2031. Vjesnik, 2.1. Vjesnikova novinska dokumentacija (kut. KOM 27).

10 S ciljem razvoja širokopojasnoga pristupa, u rujnu 2006. godine, Vlada Republike Hrvatske donijela je Strategiju razvoja širokopojasnoga pristupa u Republici Hrvatskoj do 2008. godine, u kojoj je glavni strateški cilj bio povećati broj korisnika širokopojasnoga pristupa kao temeljne infrastrukture za izgradnju informacijskoga društva i gospodarstva utemeljenoga na znanju Interneta. "Strategija razvoja širokopojasnog pristupa u RH do 2008. godine," (Republika Hrvatska, Ministarstvo mora, turizma, prometa i razvitka, 2006), pristupljeno 13. veljače 2020., https://www.hakom.hr/userDocsImages/ 
reni su preduvjeti za praktičnije i efikasnije pronalaženje novih medijskih sadržaja. Stoga je uslijedila kompromisna odluka Društva Vjesnik i nadležnih institucija o prestanku nadopunjavanja dokumentacijske zbirke novoobjavljenim novinskim člancima i njezine predaje Hrvatskoj izvještajnoj novinskoj agenciji.

Početkom 2013. godine Hrvatska novinska izvještajna agencija ušla je u postupak restrukturiranja s ciljem smanjenja kumulativnoga financijskoga gubitka u iznosu 9,3 milijuna kuna. Odjel Hina informacijska baza Informacijsko dokumentacijski centar (HIB IDC) u potpunosti je ugašen, a zbirku je zajedno sa šestero djelatnika sporazumno preuzeo Hrvatski državni arhiv. ${ }^{11}$ Postupak reguliranja pravnoga statusa Vjesnikove novinske dokumentacije okončan je iste godine njezinim proglašenjem kulturnim dobrom Republike Hrvatske. ${ }^{12}$

\section{Dosadašnje spoznaje i metodologija}

Dostupni izvori o strateškom planiranju obrade, provedenim postupcima zaštite i korištenju Vjesnikove novinske dokumentacije u razdoblju od njezina nastanka do predaje Hrvatskomu državnomu arhivu nisu osobito brojni. Tomu posebno pridonosi činjenica da je ostala nepoznata sudbina cjelokupnoga arhivskoga gradiva nastaloga radom izdavačke kuće Vjesnik. ${ }^{13}$ Ipak, analizirajući funkciju Vjesnikove novinske dokumentacije u okviru matične izdavačke kuće i javnoga servisa na temelju dostupnih izvora i literature moguće je zaključiti da je u navedenom razdoblju zbirku koristio velik broj istraživača u stručne i obrazovne svrhe. Osim toga, uvidom u rješenja Državnoga arhiva u Zagrebu iz 1994. i 2006. godine, koja su izdana u postupku obavljanja stručnoga nadzora nad zaštitom

javnarasprava/rkazic/159/Strategija.broadbrandRH.pdf. „Od 1998. u RH je uslijedio eksponencijalni porast broja online medija [...] Posljednji klasični medij koji je pokrenuo online izdanje bio je Jutarnji list. Svoje online izdanje predstavio je tek u prosincu 2005." Mato Brautović, Online novinarstvo (Zagreb: Školska knjiga, 2011), str. 25-27.

11 “Izvješće o radu Upravnog vijeća Hine za 2013.," (HINA, Upravno vijeće, 2014), pristupljeno 20. veljače 2020., https://www.hina.hr/Content/Static/Uv_2013.pdf.

12 Izvod iz registra kulturnih dobara $\mathrm{RH}, \mathrm{NN} 3 / 2013$; Lista zaštićenih kulturnih dobara, NN $126 / 2013$.

13 Dana 27. svibnja 2013. predstavnici Hrvatskoga državnoga arhiva proveli su izvanredni nadzor u trgovačkom društvu Vjesnik d. d. s ciljem identifikacije arhivskoga gradiva nastaloga djelovanjem izdavačke kuće Vjesnik radi proglašenja kulturnim dobrom te eventualnoga preuzimanja u HDA, barem za razdoblje do njegove pretvorbe 1993. godine. U naknadno sastavljenoj Službenoj zabilješci HDA o uvidu u dokumentaciju nekadašnje izdavačke kuće Vjesnik od 10. lipnja 2013. (KLASA: 612-06/1306/41, URBROJ: 565-09/5-13-2) zaključno je konstatirano da "gradivo viđeno na obje lokacije zasigurno čini manji dio cjeline koja je morala nastajati za tako dugi niz godina djelovanja kuće Vjesnik (od 1940!), pa će se obavezno nastojati na pregledu ukupnoga prostora nebodera u Slavonskoj aveniji 4 gdje se možebitno čuva arhivsko gradivo Vjesnika«. Budući da su nakon toga u HDA preuzete samo Vjesnikove zbirke, odnosno fototeka redakcije lista Vjesnik i Vjesnikova novinska dokumentacija, koja je ubrzo proglašena kulturnim dobrom, za pretpostaviti je da traženo gradivo u Vjesnikovu neboderu nakon pregleda nije pronađeno. 
arhivskoga i dokumentarnoga gradiva imatelja Novi Vjesnik d.d. i Vjesnik d.d., razvidno je da Društvo Vjesnik nije provodilo propisane postupke u svezi s čuvanjem, postupanjem, zaštitom i evidentiranjem Vjesnikove dokumentacijske zbirke, zbog čega je nadležni arhiv izdao mjere zaštite i rokove za njihovu provedbu. ${ }^{14}$ Predajom zbirke Hrvatskoj izvještajnoj novinskoj agenciji u potpunosti je završeno razdoblje njezine klasične obrade. Novi imatelj, podržan financijskim sredstvima Ministarstva kulture, ${ }^{15} \mathrm{u}$ meritum je stavio digitalizaciju kao rješenje za njezinu dostupnost i dugoročnu zaštitu. Razvojni projekt digitalizacije Vjesnikove dokumentacijske zbirke i povezivanje s postojećom bazom podataka EVA predstavljen je znanstvenoj zajednici 2007. godine na međunarodnoj konferenciji INFuture2007: Digital information and Heritage. Unatoč pozitivnim znanstvenim recenzijama projekta i financijskoj potpori Ministarstva kulture, zbirka je do 2013. godine tek manjim dijelom digitalizirana, a sredstva su preusmjerena na projekt Media monitoring usluge. ${ }^{16}$ Razdoblje provedbe projekta digitalizacije u okviru Hrvatske izvještajne novinske agencije bilo je obilježeno medijskim natpisima o neopravdano visokoj cijeni korištenja zbirke koja je naplaćivana vanjskim korisnicima. ${ }^{17}$ Unatoč tomu, revizijom poslovanja Hrvatske izvještajne novinske agencije u postupku restrukturiranja potvrđeno je da su se gubitci, generirani od 2009., u najvećoj mjeri odnosili na gubitke Odjela HIB IDC. S mjesečnim prihodima od 41.000 kuna, taj Odjel nije osiguravao dostatne prihode ni za pokriće plaća 14 djelatnika, koje su mjesečno iznosile gotovo 130.000 kuna. ${ }^{18}$

Pitanje dostupnosti i dugoročne zaštite Vjesnikove dokumentacijske zbirke relevantno je za novinarsku struku i istraživače od samoga početka njezina formiranja, a posebice je intenzivirano u razdoblju neuspjeloga pokušaja digitalizacije u okviru Hrvatske izvještajne novinske agencije. Proglašenjem zbirke kulturnim dobrom Republike Hrvatske i predajom u matični arhiv Hrvatske osigurano je njezino kontinuirano i neograničeno korištenje, u skladu sa Zakonom o arhivskom gradivu i arhivima te podzakonskim aktima, no ne i potpuna dostupnost te dugoročna zaštita koju omogućuju suvremeni postupci digitalizacije pisanoga kulturnoga nasljeđa.

Slijedom navedenoga, cilj je ovoga rada istražiti relevantnost Vjesnikove novinske dokumentacije kao kulturnoga dobra Republike Hrvatske i arhivskoga

\footnotetext{
14 Državni arhiv u Zagrebu, Pismohrana, rješenja od 22. srpnja 1994. (KLASA: 612-06/94-15/77) i od 10. veljače 2006. (KLASA: UP/I-612-06/06-15/02, URBROJ: 251-23-03/1-06-2).

15 Ministarstvo kulture u 2006. godini podržalo je Razvojni projekt povezivanja Hine i Novinske dokumentacije Vjesnika s 4,500.000 kuna. "Godišnje izvješće za 2006.," (Republika Hrvatska, Ministarstvo kulture, 2007), pristupljeno 18. veljače 2020., https:/www.min-kulture.hr/userdocsimages/ dokumenti/Izvjestaj\%20MK\%20za\%20CD.pdf.

16 “Izvješće o radu Upravnog vijeća Hine za 2013.," str. 4.

17 Usp. Igor Laić, "Novinska arhiva skrivena u Kerestincu," H-Alter, 25. lipnja 2012., pristupljeno 20. veljače 2020., https://www.h-alter.org/vijesti/novinska-arhiva-skrivena-u-kerestincu.

18 “Izvješće o radu Upravnog vijeća Hine za 2013.," str. 4.
} 
izvora za znanstvena i stručna istraživanja, na temelju kojega će biti moguće odgovoriti na pitanje o nužnosti njezine cjelovite digitalizacije, uzimajući u obzir dosadašnje iskustvo pokušaja pretvorbe zbirke u digitalni oblik i rezultate pregleda mrežno dostupnih novina i časopisa iz razdoblja od 1964. do 1990. s područja Socijalističke Federativne Republike Jugoslavije (SFRJ), odnosno od 1991. do 2006. godine s područja Republike Hrvatske.

U znanstveno-istraživačkom postupku ovoga rada korištena je metoda analize sadržaja strukturiranoga popisa Vjesnikove dokumentacijske zbirke te statistička metoda na temelju podataka iz službenih izvještaja o radu Hrvatskoga državnoga arhiva i podataka Korisničke službe i čitaonice Hrvatskoga državnoga arhiva u razdoblju od 1. lipnja 2013. do 31. prosinca 2019. godine. Osim navedenih metoda, s ciljem utvrđivanja usklađenosti strukturiranoga popisa Vjesnikove novinske dokumentacije i novinskoga sadržaja u tehničkim jedinicama, koje je neophodno za učinkovito korištenje zbirke u konvencionalnom obliku, dodatno je pristupljeno analizi stratificiranoga uzorka zbirke od minimalno 1\% tehničkih jedinica iz svake tematske cjeline. Konačno, s ciljem pronalaženja odgovora na pitanje o nužnosti cjelovite digitalizacije Vjesnikove novinske zbirke, u radu je objavljen pregled mrežno dostupnih novina i časopisa s područja SFRJ i Republike Hrvatske, objavljenih u razdoblju njezine klasične obrade.

\section{Analiza sadržaja strukturiranoga popisa Vjesnikove novinske dokumentacije}

Vjesnikova novinska dokumentacija sadrži oko 12 milijuna novinskih članaka ${ }^{19}$ prikupljenih u razdoblju od 1964. do 2006. godine u izdavačkoj kući Vjesnik. Osim što sadrži novinske članke iz Vjesnikovih izdanja, zbirka također uključuje i novinske članke objavljene u izdanjima drugih izdavačkih kuća s područja SFRJ, odnosno Republike Hrvatske. Iako ne postoji dostupan izvor iz kojega bi mogao biti utvrđen točan popis svih novina i časopisa koji su obrađeni u okviru Vjesnikove novinske dokumentacije, na temelju pregleda stratificiranoga uzorka od 1\% tehničkih jedinica iz svake tematske cjeline zbirke, moguće je zaključiti da su sustavno prikupljani i obrađivani svi dnevnici te bitniji politički tjednici i časopisi. U početku su prikupljeni i obrađeni novinski članci odlagani u osnovne tematske cjeline poput privrede, vanjske politike, unutarnje politike, sporta, kulture, a kasnije, posebice početkom 1980-ih godina, zbirka je bila proširena i drugim tematskim cjelinama. ${ }^{20}$

\footnotetext{
19 Točan broj novinskih članaka u okviru Vjesnikove novinske dokumentacije nije utvrđen, stoga je navedena okvirna procjena Hrvatske novinske izvještajne agencije u postupku analize i predstavljanja razvojnoga projekta digitalizacije. Usp. Željko Hodonj i Lana Žaja, “Mediji i demokracija,” str. 229.

20 Prema navodima Anđelke Grubišić Čabo, arhivistice koja je radila na obradi novinskih članaka Vjesnikove novinske dokumentacije. Usp. Kristina Balun, "Zlatni rudnik novinskih isječaka uskoro
} 
Vjesnikova novinska dokumentacija preuzeta je u Hrvatski državni arhiv sredinom 2013. godine u obliku 6.105 registratora i 26 ladica kartoteke, odnosno u količini od oko $580 \mathrm{~d} / \mathrm{m}$. Zbirka čini podseriju arhivskoga fonda HR-HDA2031. Vjesnik te je strukturirana prema dokumentu Tehnički popis VND gradiva, koji je izradila Hrvatska izvještajna novinska agencija za potrebu provedbe projekta digitalizacije. U svrhu primopredaje navedeni je popis djelomično izmijenjen na način da su u izvornom obliku zadržani svi izvorni naslovi i opis sadržaja te dodane nove oznake tehničkih jedinica koju tvore slovčana kartica područja i tekući broj te redni broj registratora u svakom području, a polja s oznakama tehničkih jedinica i smještaja na policama prije preuzimanja uklonjena su. Svi su novinarski članci raspoređeni u 14 osnovnih tematskih cjelina, odnosno područja. Unutar svakoga područja dalje su formirane veće ili manje tematske podcjeline, u kojima su isječci odloženi uglavnom prema kronološkom redoslijedu. $\mathrm{Na}$ svakom članku otisnut je naslov novina ili časopisa i datum objavljivanja. ${ }^{21}$ Tijekom 2018. godine Hrvatski državni arhiv, s ciljem povećanja stupnja zaštite Vjesnikove novinske dokumentacije, započeo je s postupkom zamjene registratora s arhivskim kutijama, što je okončano krajem 2019. godine. Nakon navedenih aktivnosti imatelj je strukturirani popis zbirke iz 2013. godine dopunio kolonom koja označava brojeve novih tehničkih jedinica, odnosno arhivskih kutija, unutar pojedine tematske podcjeline. $S$ obzirom na to da novi strukturirani popis Vjesnikove novinske dokumentacije ne sadrži analitički popis novinskih članaka unutar tematskih podcjelina, njegova analiza provedena je na temelju prethodnih arhivističkih opisa sadržaja tehničkih jedinica, koji u pravilu označavaju ključne riječi iz naslova i teksta novinskih članaka.

U Grafikonu 1 prikazana je struktura Vjesnikove dokumentacijske zbirke $s$ naslovima svih 14 osnovnih tematskih cjelina te količinski udio pojedine tematske cjeline u ukupnoj količini zbirke. ${ }^{22}$

\footnotetext{
dostupan i u digitalnom obliku?” Global: Novine za studentska i društvena pitanja, kulturu i sport 1, br. 1 (svibanj 2014.): str. 4-5.

21 “Popis Vjesnikove novinske dokumentacije," Hrvatski državni arhiv, 2013., str. 2, pristupljeno 4. ožujka 2020., http://arhinet.arhiv.hr/details.aspx?ItemId=2_6536.

22 Prilikom izrade grafikona korišteni su podatci o količinskom udjelu novoformiranih tehničkih jedinica (arhivskih kutija) u pojedinoj tematskoj cjelini zbirke. Usp. "Popis Vjesnikove novinske dokumentacije: Odsjek za arhivsko gradivo od 1991.," (Hrvatski državni arhiv, 2019).
} 


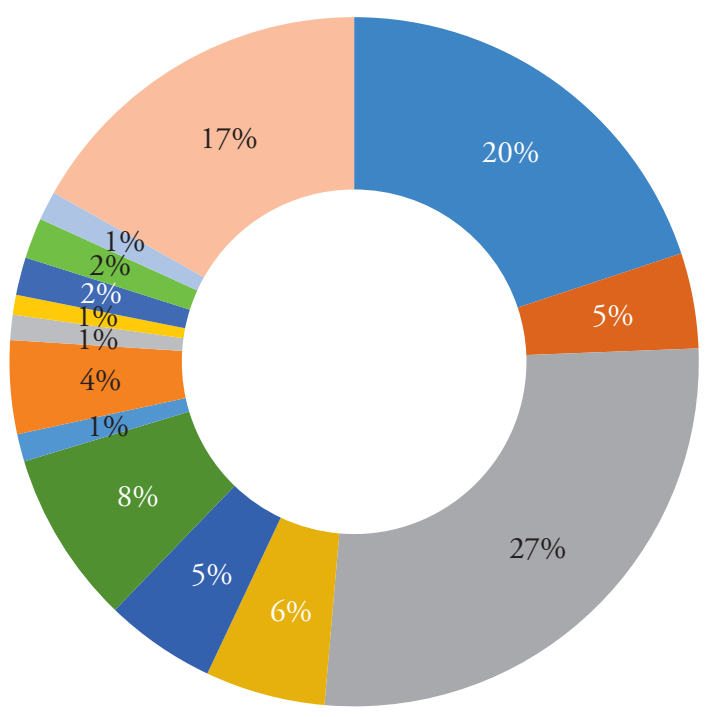

Javne osobe

Unutarnja politika

- Hrvatska vanjska politika: Svijet: Međunarodni odnosi

Društvo: Zdravstvo: Socijalna skrb

- Sudstvo: Kriminal

- Kultura

- Odgoj i obrazovanje

Sport

Znanost

Religija

- Mediji: Komunikacije

Promet

Ekologija

Ekonomija: Gospodarstvo: Financije

Grafikon 1. Količinski udjeli tematskih cjelina Vjesnikove novinske dokumentacije (izradila autorica).

Gotovo dvije trećine dokumentacijske zbirke odnosi se na novinske članke koji pripadaju tematskim cjelinama: Hrvatska vanjska politika: Svijet: Mecunarodni odnosi (27\%), Javne osobe (20\%) te Ekonomija: Gospodarstvo: Financije (17\%). Količinski su manje zastupljene pretežno tematske cjeline (Grafikon 1) formirane 80 -ih godina 20 . stoljeća.

Bitan dio zbirke čini tematska cjelina Javne osobe, koja sadrži 60.365 dosjea osoba iz domaćega i svjetskoga javnoga života, raspoređenih u 877 arhivskih kutija. Dosjei osoba odloženi su unutar tematske cjeline abecednim redom prezimena osoba. Sâm popis Vjesnikove dokumentacijske zbirke, radi lakšega pretraživanja dosjea javnih osoba, osim njihovih imena i prezimena, također sadrži i dodatne informacije poput profesija osoba s istim imenima i prezimenima ili temu i žanrove novinskih članaka većih dosjea, primjerice predsjednika država. Iako tematska cjelina Javne osobe sadrži najveći broj podcjelina, odnosno u tom slučaju dosjea, upravo zbog dobro strukturiranoga popisa navedene tematske cjeline, pretraživanje i pronalaženje novinskih članaka o određenoj javnoj osobi brzo je, jednostavno i učinkovito. ${ }^{23}$

\footnotetext{
23 “Popis Vjesnikove novinske dokumentacije: Odsjek za arhivsko gradivo od 1991.," str. 1-27.
} 
Novinski članci tematske cjeline Unutarnja politika raspoređeni su u ukupno 122 tematske podcjeline, odnosno u 198 arhivskih kutija. Najveći dio novinskih članaka te cjeline obrađuju djelovanje državnih poglavara, predstavničkih tijela zakonodavne i izvršne vlasti te jedinica lokalne i regionalne samouprave na području Socijalističke Republike Hrvatske i Republike Hrvatske, kao i uspostavu političkoga pluralizma, provedbu izbora i djelovanje političkih stranaka u Republici Hrvatskoj. Osim toga, bitan dio cjeline čine novinski članci iz razdoblja Domovinskoga rata, koji su unutar tematskih podcjelina raspoređeni većinom prema imenima mjesta i područja ratnih sukoba ili hrvatskih vojno-redarstvenih akcija i operacija. Osnovni je nedostatak cjeline učestalo preklapanje ključnih riječi u različitim tematskim podcjelinama i izostanak opisa sadržaja pojedinih tehničkih jedinica, što može otežati korisničko pretraživanje i pronalaženje novinskih članaka u okviru određenih tema, primjerice novinskih članaka na temu djelovanja političkih stranaka. ${ }^{24}$

Tematska cjelina Hrvatska vanjska politika: Svijet: Medunarodni odnosi, uzimajući u obzir dodijeljene slovčane kratice područja i brojeve tehničkih jedinica, načelno je podijeljena na dva dijela: Hrvatska vanjska politika te Svijet i Međunarodni odnosi. Novinski članci prvoga dijela cjeline raspoređeni su u 256 tematskih podcjelina, odnosno u 534 arhivske kutije, a drugi je dio pohranjen u 657 arhivskih kutija u okviru 283 tematske podcjeline. Prema abecednom redoslijedu imena kontinenata, dijelova kontinenata i država formirane su tematske podcjeline za većinu novinskih članaka, jer informiraju o događajima i prilikama na navedenim područjima ili lokacijama unutar njih. Pored toga, znatan dio novinskih članaka obrađuje ustroj i djelovanje društveno-političkih organizacija u SFRJ, događaje uoči i za vrijeme političke krize u Jugoslaviji te bilateralne odnose SFRJ i Republike Hrvatske s pojedinim državama. Iako velik broj tematskih podcjelina i tehničkih jedinica iziskuje dužu korisničku pretragu strukturiranog popisa te tematske cjeline, upravo zbog činjenice da je većina podcjelina formirana abecednim redom mjesta događaja, istraživanje novinskih članaka u okviru određene teme vezane za vanjsku politiku, međunarodne odnose i prilike u svijetu jednostavno je i učinkovito. ${ }^{25}$

Četvrta tematska cjelina Društvo: Zdravstvo: Socijalna skrb čine novinski članci raspoređeni u 111 tematskih podcjelina, u 247 arhivskih kutija. Većina novinskih članaka te cjeline tematski obrađuje demografska i sociološka pitanja, primjerice iseljeništvo, migracije, zapošljavanje, borbu za radnička prava, mirovinsko i invalidsko osiguranje, prava i položaj djece i žena u društvu, devijantna ponašanja, roditeljstvo, brak i prehranu, kao i pitanja vezana za zdravstvo i zdravstvenu zaštitu u SFRJ i Republici Hrvatskoj. Osnovni nedostatak strukturiranoga

\footnotetext{
24 “Popis Vjesnikove novinske dokumentacije: Odsjek za arhivsko gradivo od 1991.," str. 28-42.

25 "Popis Vjesnikove novinske dokumentacije: Odsjek za arhivsko gradivo od 1991.," str. 43-170.
} 
popisa te tematske cjeline izostanak je opisa sadržaja u 8 arhivskih kutija, koji se odnose na tematsku podcjelinu Društvo. ${ }^{26}$

Novinski članci vezani za sudstvo i kriminal pohranjeni su u sljedećoj istoimenoj tematskoj cjelini, unutar 230 arhivskih kutija, odnosno 143 tematskih podcjelina. Dokumentirani su slučajevi sudskih postupaka i presuda zbog raznih kaznenih djela, primjerice ratnih zločina, genocida, atentata, privrednih prijestupa, svih oblika nasilja uključujući terorizam, ubojstva, otmice, otuđenje imovine, ucjene, seksualna zlostavljanja, prijetnje i klevete. Neočekivano, tematska cjelina Sudstvo: Kriminal sadrži novinske članke koji informiraju o izbjeglicama, prognanicima i humanitarnoj pomoći tijekom ratnih zbivanja 1990-ih godina na području SFRJ, tim više što je razvidno da prethodna tematska cjelina Društvo: Zdravstvo: Socijalna skrb sadrži novinske članke o migracijama stanovništva, a u opisima sadržaja pojedinih arhivskih kutija i ključne riječi prognanici i izbjeglice. ${ }^{27}$

Tematsku cjelinu Kultura $i$ umjetnost čine novinski članci razvrstani u 133 podcjeline i pohranjeni u 359 arhivskih kutija. Tematske podcjeline većinom su sadržajno grupirane na umjetnička polja i grane ili uz to vezane teme, primjerice književnost, časopise, izdavaštvo, muzejsko-galerijsku i izložbenu djelatnost, kiparstvo, strip, film, kazalište, ozbiljnu glazbu, operu, balet, zabavnu glazbu, arhitekturu i zaštitu spomenika kulture. Strukturirani popis te cjeline sadrži detaljne opise sadržaja za gotovo sve tehničke jedinice, što uvelike pojednostavljuje korisnički postupak pretraživanja novinskih članaka. ${ }^{28}$

Najmanji postotak novinskih članaka, samo $8 \%$ od ukupne količine zbirke, razvrstano je u tematske cjeline Odgoj i obrazovanje (1\%), Znanost (1\%), Religija (1\%), Komunikacije: Mediji (2\%), Promet (2\%) i Ekologija (1\%), prvenstveno jer su formirane kasnije. Od navedenih cjelina najveći broj podcjelina ima područje Komunikacije: Mediji, unutar kojega su razvrstani novinski članci o javnom informiranju, masovnim medijima te statusu i djelovanju novinarske struke. U okviru te cjeline moguće je pratiti uređivačke politike informativnih kuća i novinskih redakcija u SFRJ i Republici Hrvatskoj, utjecaj političkih elita i djelovanje jugoslavenske državne i partijske kontrole nad medijima do 1990. godine. Osim toga, navedena tematska cjelina Vjesnikove dokumentacijske zbirke pruža informacije o zakonodavnom okviru informativne djelatnosti tijekom socijalističkoga upravljanja u Hrvatskoj te utjecaju demokratskih promjena na razvoj slobode govora i uredničku neovisnost medija. Osobito važni novinski članci tematski obrađuju rad društava i udruženja novinara, njihove skupove, savjetovanja, zatim tužbe protiv novinara i novinskih redakcija te razne oblike nasilja nad

26 "Popis Vjesnikove novinske dokumentacije: Odsjek za arhivsko gradivo od 1991.," str. 171-185.

27 “Popis Vjesnikove novinske dokumentacije: Odsjek za arhivsko gradivo od 1991.," str. 186-199.

28 “Popis Vjesnikove novinske dokumentacije: Odsjek za arhivsko gradivo od 1991.," str. 200-228. 
novinarima, koja uključuju ubojstva, otmice i ranjavanja tijekom ratnih sukoba. Unatoč manjkavosti strukturiranih popisa najmanjih tematskih cjelina, koje proizlaze iz ponavljanja ključnih riječi u naslovima podcjelina i opisu sadržaja, upravo zbog male količine tehničkih jedinica i kratkoga popisa cjeline korisničko istraživanje i pronalaženje određenih novinskih članaka brzo je i ne zahtijeva fizički pregled većih količina arhivskih kutija. ${ }^{29}$

Nepostojanje jasne strategije u navođenju ključnih riječi u strukturiranom popisu zbirke može se utvrditi i u okviru tematske cjeline Sport, koja sadrži 97 podcjelina i 193 arhivske kutije. Na samom početku popisa cjeline nalaze se novinski članci na temu međunarodnih natjecanja, koji su razvrstani prema vrsti sporta. Nakon toga slijede podcjeline Olimpijada i Univerzijada te abecednim redom poredani dosjei sportskih klubova, a zatim ponovno podcjeline prema pojedinoj vrsti sporta. ${ }^{30}$

Posljednja tematska cjelina u Vjesnikovoj dokumentacijskoj zbirci sadrži 225 podcjelina i 743 arhivske kutije, unutar kojih su razvrstani novinski članci vezani za gospodarstvo, ekonomiju i financije. Podcjeline te tematske cjeline odnose se na ekonomsku politiku, ekonomske odnose SFRJ s drugim zemljama, ekonomske prilike u Republici Hrvatskoj te pojedine privredne djelatnosti poput industrije, brodogradnje, poljoprivrede, energetike, rudarstva, građevinarstva, trgovine, ugostiteljstva i bankarstva. Budući da je riječ o velikoj tematskoj cjelini te da se ključne riječi u naslovima podcjelina i opisima sadržaja često preklapaju, istraživanje određenih tema u okviru gospodarstva i financija zahtijeva pregled većega broja tehničkih jedinica. ${ }^{31}$

U tablici koja slijedi prikazani su rezultati istraživanja podudarnosti naslova podcjelina, odnosno dosjea i opisa sadržaja arhivskih kutija iz strukturiranoga popisa s temama novinskih članaka iz pojedine tehničke jedinice zbirke te očuvanosti kronološkoga i abecednoga poretka novinskih članaka unutar tehničkih jedinica, koje je provedeno na stratificiranom uzorku od minimalno $1 \%$ arhivskih kutija iz svake tematske cjeline, odnosno na stratificiranom uzorku od ukupno 49 arhivskih kutija.

\footnotetext{
29 “Popis Vjesnikove novinske dokumentacije: Odsjek za arhivsko gradivo od 1991.," str. 229-234, 251-351.

30 “Popis Vjesnikove novinske dokumentacije: Odsjek za arhivsko gradivo od 1991.," str. 235-250.

31 “Popis Vjesnikove novinske dokumentacije: Odsjek za arhivsko gradivo od 1991.," str. 285-351.
} 
Tablica 1. Analiza podudarnosti naslova podcjelina, odnosno dosjea i opisa sadržajas temama pripadajućih novinskih članaka te očuvanosti kronološkoga i abecednoga poretka novinskih članaka unutar tehničkih jedinica (izradila autorica prema podatcima Korisničke službe i čitaonice HDA). ${ }^{32}$

\begin{tabular}{|l|c|c|c|c|}
\hline Tematske cjeline & $\begin{array}{c}\text { Broj } \\
\text { arhivskih } \\
\text { kutija }\end{array}$ & $\begin{array}{c}\text { Podudarnost } \\
\text { naslova } \\
\text { podcjelina s } \\
\text { obrađenim } \\
\text { temama }\end{array}$ & $\begin{array}{c}\text { Podudarnost } \\
\text { opisa } \\
\text { tehničke } \\
\text { jedinice s } \\
\text { obradenim } \\
\text { temama }\end{array}$ & $\begin{array}{c}\text { Očuvanost } \\
\text { kronološkoga i } \\
\text { abecednoga } \\
\text { poretka novinskih } \\
\text { članaka unutar } \\
\text { arhivskih kutija }\end{array}$ \\
\hline Javne osobe & 9 & $100 \%$ & $100 \%$ & $88,88 \%$ \\
\hline Unutarnja politika & 2 & $100 \%$ & $100 \%$ & $100 \%$ \\
\hline $\begin{array}{l}\text { Hrvatska vanjska } \\
\text { politika: Svijet: } \\
\text { Međunarodni odnosi }\end{array}$ & 12 & $100 \%$ & $83,33 \%$ & $83,33 \%$ \\
\hline $\begin{array}{l}\text { Društvo: Zdravstvo: } \\
\text { Socijalna skrb }\end{array}$ & 3 & $100 \%$ & $100 \%$ & $100 \%$ \\
\hline Sudstvo: Kriminal & 3 & $100 \%$ & $100 \%$ & $100 \%$ \\
\hline Kultura i umjetnost & 4 & $100 \%$ & $100 \%$ & $75 \%$ \\
\hline Odgoj i obrazovanje & 1 & $100 \%$ & $100 \%$ & $100 \%$ \\
\hline Sport & 2 & $100 \%$ & $100 \%$ & $100 \%$ \\
\hline Znanost & 1 & $100 \%$ & $100 \%$ & $100 \%$ \\
\hline Religija & 1 & $100 \%$ & $100 \%$ & $100 \%$ \\
\hline Komunikacije: Mediji & 1 & $100 \%$ & $100 \%$ & $100 \%$ \\
\hline Promet & 1 & $100 \%$ & $100 \%$ & $100 \%$ \\
\hline Ekologija & 1 & $100 \%$ & $100 \%$ & $100 \%$ \\
\hline $\begin{array}{l}\text { Ekonomija: } \\
\text { Gospodarstvo: }\end{array}$ & 8 & $100 \%$ & $87,5 \%$ & $75 \%$ \\
\hline Financije & 1 & & & \\
\hline
\end{tabular}

Iz navedene analize proizlazi da se naslovi podcjelina i dosjea zbirke $u$ potpunosti podudaraju s temama pripadajućih novinskih članaka, a podudarnost opisa sadržaja arhivskih kutija iz strukturiranoga popisa s temama novinskih čla-

32 Rezultati analize dobiveni su dijeljenjem broja arhivskih kutija u kojima je uočena podudarnost naslova podcjelina (dosjea) i sadržaja tehničkih jedinica s temama novinskih članaka, odnosno očuvanost prvobitnoga poretka novinskih članaka unutar arhivskih kutija, s brojem arhivskih kutija unutar svake tematske cjeline. Primjerice, u okviru tematske cjeline Javne osobe očuvanost prvobitnoga poretka novinskih članaka unutar tehničkih jedinica uočena je u 8 arhivskih kutija od 9 promatranih, što iznosi $88,88 \%(8: 9 \times 100)$. 
naka unutar istih, kao i očuvanost kronološkoga i abecednoga poretka novinskih članaka unutar tehničkih jedinica veća je kod onih tematskih cjelina koje sadrže manji broj podcjelina i tehničkih jedinica.

$\mathrm{Na}$ temelju provedene analize sadržaja strukturiranoga popisa Vjesnikove novinske dokumentacije i stratificiranoga uzorka zbirke, koji čini minimalno 1\% arhivskih kutija iz svake tematske cjeline, moguće je utvrditi sljedeće:

1. Podatci iz strukturiranoga popisa zbirke (brojevi tehničkih jedinica, naslovi tematskih cjelina i podcjelina) u cijelosti odgovaraju stvarnomu stanju zbirke.

2. Osnovni nedostatak u pojedinim tematskim cjelinama učestalo je preklapanje ključnih riječi u različitim podcjelinama ${ }^{33}$ te izostanak opisa sadržaja pojedinih tehničkih jedinica, zbog čega je otežana identifikacija i pronalaženje novinskih članaka unutar istih.

3. Gotovo u cijelosti su novinski članci odlagani u pripadajuće tematske cjeline, odnosno samo je u tematskoj cjelini Sudstvo: Kriminal uočeno da bi manji dio novinskih članaka, s obzirom na temu koju obrađuju, trebali biti odloženi u tematsku cjelinu Društvo: Zdravstvo: Socijalna skrb.

4. Visok postotak podudarnosti opisa sadržaja tehničkih jedinica $s$ temama novinskih članaka u okviru istih (aritmetička sredina, tj. $\mathrm{x}=$ $97,91 \%)$ te očuvanosti kronološkoga i abecednoga poretka novinskih članaka (aritmetička sredina, tj. $\mathrm{x}=94,44 \%$ ) omogućuje učinkovito pronalaženje identificiranih i sadržajno opisanih novinskih članaka unutar arhivskih kutija.

\section{Korištenje Vjesnikove novinske dokumentacije u Središnjoj čitaonici Hrvatskoga državnoga arhiva u razdoblju od 1. lipnja 2013. do 31. prosinca 2019. godine}

Prilikom prve prijave za rad u čitaonici Hrvatskoga državnoga arhiva korisnici su dužni ispuniti osnovne podatke u Prijavnici za korištenje gradiva, koji uključuju ime i prezime, datum rođenja, mjesto rođenja, podatak o državljanstvu, adresu prebivališta i boravišta, broj osobne iskaznice, odnosno putovnice, te broj telefona ili adresu elektroničke pošte. Osim obveznih podataka, Prijavnica za korištenje gradiva Hrvatskoga državnoga arhiva također omogućuje

\footnotetext{
33 Istražujući novinske članke u okviru Vjesnikove novinske dokumentacije koji mogu poslužiti kao izvor za povijest Istre, Vlatka Lemić također slično utvrđuje: „Pregledom novinskih isječaka unutar pojedinih tematskih cjelina, vidljiv je subjektivni pristup dokumentalista koji su ih predmetno obrađivali s obzirom na česta preklapanja i ponavljanja istih riječi i sadržajnih odrednica, međutim, to ne umanjuje njezinu informacijsku vrijednost." Vlatka Lemić, "Vjesnikova novinska dokumentacija u Hrvatskom državnom arhivu kao izvor za istraživanje povijesti Istre," Vjesnik istarskog arhiva 25 (2018): str. 32.
} 
neobvezan upis sljedećih dopunskih podataka korisnika: ime ustanove zaposlenja ili studiranja, zanimanje, zvanje, svrhu korištenja, temu istraživanja, naslov i signaturu arhivskoga fonda ili zbirke koju namjeravaju istraživati te podatak hoće li i gdje objaviti istraženo gradivo. ${ }^{34}$ Neminovno je da Hrvatski državni arhiv i dalje poštuje privatnost svojih korisnika, kao i ostali državni arhivi u Hrvatskoj. Međutim, razvidno je da ne postoji informacijska i komunikacijska strategija prikupljanja dodatnih podataka i analize korisnika na internim osnovama, barem za potrebe vlastitoga poslovanja. ${ }^{35}$ Naime, prvotni je istraživački plan korištenja Vjesnikove novinske zbirke u Hrvatskom državnom arhivu, s uključenom analizom obrazovne strukture korisnika zbirke te svrhom korištenja navedene zbirke, zbog nepotpunosti navedenih podataka obustavljen. Neuspio pokušaj se posebice vezuje uz razdoblje od kada spomenuti podatci postaju dopunski i neobvezujući u Prijavnici za korištenje gradiva.

U sljedećim tablicama, na temelju podataka Korisničke službe Hrvatskoga državnoga arhiva i godišnjih izvješća o radu Hrvatskoga državnoga arhiva, kao dodatnoga oslonca istraživanja, prikazan je udio korisničkih zahtjeva za istraživanjem Vjesnikove novinske dokumentacije (VND) u ukupnoj količini korisničkih zahtjeva za istraživanje gradiva u Hrvatskom državnom arhivu u razdoblju od 1. lipnja 2013. do 31. prosinca 2019. godine te količinski udio Vjesnikove novinske dokumentacije u ukupnoj količini arhivskoga gradiva Hrvatskoga državnoga arhiva. ${ }^{36}$

\footnotetext{
34 "Prijavnica za korištenje arhivskog gradiva," (Hrvatski državni arhiv, s. a.), pristupljeno 6. rujna 2020., http://zagreb.arhiv.hr/hr/koristenje/prijavnica.pdf.

35 Goran Pavelin predlaže izradu obimnijih korisničkih obrazaca u hrvatskim arhivima, u formi referentnoga dnevnika, koji uključuje anonimni orijentacijski intervju korisnika s proširenjem pitanja o planiranoj uporabi informacija, konciznijem određivanju korisničkoga identiteta, načinu kako je korisnik saznao za gradivo ili usluge te prirodi očekivane usluge. Referentni dnevnik također može sadržavati i upitnik koji prikuplja informacije samo do određene skupine korisnika, odnosno na odabranom uzorku istraživača tijekom određenoga vremena. Goran Pavelin, Informacijsko-komunikacijska podloga strateškog planiranja arhiva (Zadar: Državni arhiv u Zadru, 2019), str. 135.-140. i 154.-157.

${ }^{36}$ Izraženi podatci o godišnjem broju korisničkih zahtjeva evidentiranim u Središnjoj čitaonici Hrvatskoga državnoga arhiva odnose se samo na one korisnike koji su istraživali gradivo u čitaonici Arhiva. Od lipnja 2018. godine promijenjen je sustav evidentiranja korisnika na način da se bilježe samo novi korisnici, odnosno oni koji nisu prethodno zabilježeni u evidencijama korisnika HDA.
} 
Tablica 2. Pregled broja korisničkih zahtjeva u središnjoj čitaonici Hrvatskoga državnoga arhiva i udjela korisničkih zahtjeva za VND u razdoblju od 1. lipnja 2013. do 31. prosinca 2019. godine (izradila autorica na temelju podataka Korisničke službe i čitaonice $H D A$ ).

\begin{tabular}{|c|c|c|c|}
\hline Godina & $\begin{array}{c}\text { Broj korisničkih } \\
\text { zahtjeva u središnjoj } \\
\text { čitaonici HDA }\end{array}$ & $\begin{array}{c}\text { Broj korisničkih } \\
\text { zahtjeva za VND }\end{array}$ & $\begin{array}{c}\text { Udio korisničkih zahtjeva } \\
\text { za VND u broju korisničkih } \\
\text { zahtjeva u HDA }\end{array}$ \\
\hline 2013. & 486 & 73 & $15,02 \%$ \\
\hline 2014. & 1263 & 135 & $10,68 \%$ \\
\hline 2015. & 1132 & 100 & $8,83 \%$ \\
\hline 2016. & 1111 & 85 & $7,65 \%$ \\
\hline 2017. & 1194 & 143 & $11,97 \%$ \\
\hline 2018. & 1100 & 101 & $9,18 \%$ \\
\hline 2019. & 754 & 30 & $3,97 \%$ \\
\hline
\end{tabular}

Tablica 3. Udio količine gradiva VND u ukupnoj količini gradiva HDA u razdoblju od 2013. do 2019. godine (izradila autorica na temelju podataka iz izvješća o radu HDA) ${ }^{37}$

\begin{tabular}{|c|c|c|c|}
\hline Godina & $\begin{array}{c}\text { Količina arhivskoga } \\
\text { gradiva u HDA }\end{array}$ & $\begin{array}{c}\text { Količina gradiva } \\
\text { VND }\end{array}$ & $\begin{array}{c}\text { Udio količine gradiva VND } \\
\text { u količini gradiva u HDA }\end{array}$ \\
\hline 2013. & $26.900 \mathrm{~d} / \mathrm{m}$ & $580 \mathrm{~d} / \mathrm{m}$ & $2,15 \%$ \\
\hline 2014. & $27.500 \mathrm{~d} / \mathrm{m}$ & $580 \mathrm{~d} / \mathrm{m}$ & $2,1 \%$ \\
\hline 2015. & $27.500 \mathrm{~d} / \mathrm{m}$ & $580 \mathrm{~d} / \mathrm{m}$ & $2,1 \%$ \\
\hline 2016. & $29.000 \mathrm{~d} / \mathrm{m}$ & $580 \mathrm{~d} / \mathrm{m}$ & $2 \%$ \\
\hline 2017. & $29.000 \mathrm{~d} / \mathrm{m}$ & $580 \mathrm{~d} / \mathrm{m}$ & $1,93 \%$ \\
\hline 2018. & $30.000 \mathrm{~d} / \mathrm{m}$ & $580 \mathrm{~d} / \mathrm{m}$ & $1,9 \%$ \\
\hline 2019. & $30.500 \mathrm{~d} / \mathrm{m}$ & $580 \mathrm{~d} / \mathrm{m}$ & \\
\hline
\end{tabular}

\footnotetext{
37 Na temelju podataka u: "Izvješće o radu u 2013. godini," (Hrvatski državni arhiv, 2013), pristupljeno 25. svibnja 2020., http://www.arhiv.hr/Portals/0/Dokumenti/Planovi\%20i\%20izvje\%C5\%A1\% C4\%87a/Izvje\%C5\%A 1\%C4\%87e\%20o\%20radu\%20HDA\%20u\%202013.\%20godini. pdf?ver=2017-03-23-092024-000; "Izvješće o radu u 2014. godini," (Hrvatski državni arhiv, 2015), pristupljeno 25. svibnja 2020., http://www.arhiv.hr/Portals/0/Dokumenti/Planovi\%20i\%20izvje\% C5\%A1\%C4\%87a/Izvje\%C5\%A1\%C4\%87e\%20o\%20radu\%20HDA\%20u\%202014.\%20godini. pdf?ver=2017-03-23-092022-000; "Izvješće o radu u 2015. godini," (Hrvatski državni arhiv, 2016), pristupljeno 25. svibnja 2020., http://www.arhiv.hr/Portals/0/Dokumenti/Planovi\%20i\%20izvje\% C5\%A1\%C4\%87a/Izvje\%C5\%A1\%C4\%87e\%20o\%20radu\%20HDA\%20u\%202015.\%20godini. pdf?ver=2017-03-23-092021-967; “Izvještaj o radu u 2016. godini," (Hrvatski državni arhiv, 2017), pristupljeno 25. svibnja 2020., http://www.arhiv.hr/Portals/0/Dokumenti/Planovi\%20i\%20izvje\% C5\%A1\%C4\%87a/Izvje\%C5\%A1\%C4\%87e\%20o\%20radu\%20HDA\%20u\%202016.\%20godini.
} 
Iz navedenoga proizlazi da je u razdoblju od 1. lipnja 2013. do 31. prosinca 2019. godine udio korisničkih zahtjeva za istraživanje Vjesnikove novinske dokumentacije u ukupnom broju korisničkih zahtjeva evidentiranih u Središnjoj čitaonici Hrvatskoga državnoga arhiva prosječno iznosio 9,61\% (aritmetička sredina, $\mathrm{x}=9,61 \%$ ), a u razdoblju od 2013. do 2019. godine udio Vjesnikove dokumentacijske zbirke u ukupnoj količini gradiva pohranjenoga u Hrvatskom državnom arhivu prosječno je iznosio 2,02\% (aritmetička sredina, $\mathrm{x}=2,02 \%$ ). S obzirom na navedene podatke, moguće je zaključiti da je gradivo Vjesnikove novinske dokumentacije u odnosu na ostalo konvencionalno gradivo pohranjeno u Hrvatskom državnom arhivu u promatranom razdoblju korišteno u bitnoj mjeri.

Tablica 4. Pregled količine korištenih tehničkih jedinica iz pojedine tematske cjeline Vjesnikove novinske dokumentacije u razdoblju od 1. lipnja 2013. do 31. prosinca 2019. godine (izradila autorica na temelju podataka Korisničke službe i čitaonice HDA).

\begin{tabular}{|l|c|c|c|c|c|c|c|c|}
\hline Tematske cjeline & 2013. & 2014. & 2015. & 2016. & 2017. & 2018. & 2019. & Ukupno \\
\hline Javne osobe & 6 & 15 & 9 & 40 & 17 & 13 & 39 & 139 \\
\hline Unutarnja politika & 22 & 44 & 78 & 67 & 23 & 22 & 41 & 297 \\
\hline $\begin{array}{l}\text { Hrvatska vanjska } \\
\text { politika: Svijet: } \\
\text { Međunarodni odnosi }\end{array}$ & 31 & 68 & 144 & 88 & 110 & 40 & 58 & 539 \\
\hline $\begin{array}{l}\text { Društvo: Zdravstvo: } \\
\text { Socijalna skrb }\end{array}$ & 19 & 70 & 68 & 5 & 29 & 10 & 13 & 214 \\
\hline Sudstvo: Kriminal & 26 & 41 & 30 & 12 & 6 & 10 & 13 & 138 \\
\hline Kultura i umjetnost & 34 & 127 & 58 & 22 & 41 & 8 & 42 & 332 \\
\hline Odgoj i obrazovanje & 4 & 4 & 10 & 6 & 3 & 4 & 8 & 39 \\
\hline Sport & 2 & 6 & 10 & 11 & 10 & 11 & 12 & 62 \\
\hline Znanost & 6 & 8 & 6 & 5 & 1 & 6 & 0 & 32 \\
\hline Religija & 2 & 10 & 17 & 5 & 1 & 2 & 2 & 39 \\
\hline Komunikacije: Mediji & 7 & 23 & 3 & 54 & 8 & 22 & 38 & 155 \\
\hline
\end{tabular}

pdf?ver=2017-03-23-092024-000; "Izvještaj o radu u 2017. godini," (Hrvatski državni arhiv, 2018), pristupljeno 25. svibnja 2020., http://www.arhiv.hr/Portals/0/Dokumenti/Planovi\%20i\%20izvje\% C5\%A1\%C4\%87a/Izvje\%C5\%A1\%C4\%87e\%20o\%20radu\%20HDA\%20u\%202017.\%20godini. pdf?ver=2018-03-12-130526-847; "Izvještaj o radu u 2018. godini," (Hrvatski državni arhiv, 2019), pristupljeno 25. svibnja 2020., http://www.arhiv.hr/Portals/0/Dokumenti/Planovi\%20i\%20izvje\% C5\%A1\%C4\%87a/Izvje\%C5\%A1 taj\%20o\%20radu\%20HDA\%20za\%202018.godinu. pdf?ver=2020-02-05-123337-490; "Izvješće o izvršenju programa rada Hrvatskog državnog arhiva za 2019. godinu," (Hrvatski državni arhiv, 2020), pristupljeno 25. svibnja 2020., http://www.arhiv.hr/ Portals/0/Dokumenti/Planovi\%20i\%20izvje\%C5\%A1\%C4\%87a/Izvje\%C5\%A1\%C4\%87e\%20 o\%20izvr\%C5\%A1 enju\% 20programa\%20rada \%20 Hrvatskog $\% 20 \mathrm{dr} \%$ C5\%BEavnog $\% 20$ arhiva\%20za\%202019.g..pdf?ver=2020-03-09-122922-897. 


\begin{tabular}{|l|c|c|c|c|c|c|c|c|}
\hline Tematske cjeline & 2013. & 2014. & 2015. & 2016. & 2017. & 2018. & 2019. & Ukupno \\
\hline Promet & 2 & 5 & 3 & 0 & 2 & 22 & 6 & 40 \\
\hline Ekologija & 6 & 5 & 0 & 0 & 1 & 4 & 10 & 26 \\
\hline $\begin{array}{l}\text { Ekonomija: } \\
\begin{array}{l}\text { Gospodarstvo: } \\
\text { Financije }\end{array}\end{array}$ & 11 & 27 & 31 & 51 & 54 & 23 & 37 & 234 \\
\hline Ukupno & 178 & 453 & 467 & 366 & 306 & 197 & 319 & 2286 \\
\hline
\end{tabular}

Tablica 5. Usporedba udjela pojedine tematske cjeline i korištenih tehničkih jedinica u razdoblju od 1. lipnja do 31. prosinca 2019. u ukupnoj količini Vjesnikove novinske dokumentacije (izradila autorica na temelju podataka Korisničke službe i čitaonice HDA).

\begin{tabular}{|l|c|c|}
\hline Tematske cjeline & $\begin{array}{c}\text { Udio u ukupnoj } \\
\text { količini VND }\end{array}$ & $\begin{array}{c}\text { Udio korištenih tehničkih jedinica } \\
\text { u ukupnoj količini tehničkih } \\
\text { jedinica VND u od 2013. do 2019. }\end{array}$ \\
\hline Javne osobe & $20 \%$ & $3,2 \%$ \\
\hline Unutarnja politika & $5 \%$ & $6,7 \%$ \\
\hline $\begin{array}{l}\text { Hrvatska vanjska politika: } \\
\text { Svijet: Međunarodni odnosi }\end{array}$ & $27 \%$ & $12,2 \%$ \\
\hline $\begin{array}{l}\text { Društvo: Zdravstvo: } \\
\text { Socijalna skrb }\end{array}$ & $6 \%$ & $4,8 \%$ \\
\hline Sudstvo: Kriminal & $5 \%$ & $3,1 \%$ \\
\hline Kultura i umjetnost & $8 \%$ & $7,5 \%$ \\
\hline Odgoj i obrazovanje & $1 \%$ & $0,9 \%$ \\
\hline Sport & $4 \%$ & $1,4 \%$ \\
\hline Znanost & $1 \%$ & $0,7 \%$ \\
\hline Religija & $1 \%$ & $0,9 \%$ \\
\hline Komunikacije: Mediji & $2 \%$ & $3,5 \%$ \\
\hline Promet & $2 \%$ & $0,9 \%$ \\
\hline Ekologija & $1 \%$ & $0,6 \%$ \\
\hline $\begin{array}{l}\text { Ekonomija: Gospodarstvo: } \\
\text { Financije }\end{array}$ & $17 \%$ & $5,3 \%$ \\
\hline Ukupno & $100 \%$ & $51,7 \%$ \\
\hline
\end{tabular}

Tablica 4 i Tablica 5 prikazuju količine korištenih tehničkih jedinica unutar pojedine tematske cjeline te njihov udio u ukupnoj količini Vjesnikove novinske dokumentacije u razdoblju od 1. lipnja 2013. do 31. prosinca 2019. godine. 
Iz navedenih podataka Korisničke službe Hrvatskoga državnoga arhiva proizlazi da je u promatranom razdoblju korišteno ukupno 2.286 arhivskih kutija, odnosno $51,7 \%$ u odnosu na ukupnu količinu zbirke. ${ }^{38}$ Ipak, treba ukazati na mogućnost da su pojedine tehničke jedinice bile korištene više puta, pa bi stvarni udio korištenoga gradiva u tom slučaju mogao biti i manji. Također, prema podatcima Središnje čitaonice Hrvatskoga državnoga arhiva razvidno je da se u promatranom razdoblju najviše koristila količinski najzastupljenija tematska cjelina Hrvatska vanjska politika: Svijet: Medunarodni odnosi (12,2\%), a s obzirom na udjele pojedinih tematskih cjelina u ukupnoj količini zbirke, evidentan je velik interes korisnika za tematske cjeline: Kultura i umjetnost; Komunikacije: Mediji; Društvo: Zdravstvo: Socijalna skrb. Osim navedenoga, potrebno je spomenuti i podatak o korištenju tematske cjeline Javne osobe. Naime, prethodna tablica prikazuje samo broj korištenih tehničkih jedinica, ne i dodatnih 845 količinski manjih dosjea javnih osoba koji su u Korisničkoj službi i čitaonici HDA evidentirani kao korišteni predmeti, bez navedenih podataka o njihovu količinskom udjelu unutar tehničke jedinice. S obzirom na to da tematska cjelina Javne osobe sadrži 60.365 dosjea, koji su arhivirani u ukupno 877 arhivskih kutija, prosječan broj dosjea unutar arhivske kutije iznosi 68,83 , što bi u konačnici značilo da je dodatno istraživano gradivo tematske cjeline Javne osobe u prosječnoj količini od 13 arhivskih kutija. U tom smislu, stvarni količinski udio korištenoga gradiva tematske cjeline Javne osobe u ukupnoj količini Vjesnikove novinske dokumentacije nešto je veći od prikazanoga udjela korištenih tehničkih jedinica tematske cjeline u ukupnoj količini tehničkih jedinica zbirke.

\section{Digitalizacija Vjesnikove novinske dokumentacije i njezina budućnost}

Primarni razlog zbog kojega se posljednjih nekoliko desetljeća intenzivno radi na preformatiranju novinskih zbirki njihova je zaštita. ${ }^{39}$ Novine su od svih kulturnih resursa izrazito sklone oštećivanju i propadanju jer su tiskane na nekvalitetnom papiru, posebice od druge polovice 19. stoljeća. ${ }^{40}$ Razvojem digitalne tehnologije stvoreni su preduvjeti za korisnički pristup modeliranju digitalnih

\footnotetext{
38 Ukupan broj tehničkih jedinica VND prema novom strukturiranom popisu iz 2019. iznosi 4.418 arhivskih kutija.

39 Preformatiranje je prenošenje sadržaja gradiva na drugi medij. Tri su ustaljena načina preformatiranja: fotokopiranje, mikrofilmiranje i digitalizacija. Razvojem digitalne tehnologije omogućeno je ispreplitanje mikrofilmiranja i digitalizacije, na način da se prethodno mikrofilmirane novine digitaliziraju s mikrofilma ili da se digitalizirane slike pohranjuju na mikrofilm. Usp. Maja Krtalić, "Pristupi, metode i dostignuća u zaštiti novina," Vjesnik bibliotekara Hrvatske 51 (2008): str. 1-18.

40 Krtalić, "Pristupi, metode i dostignuća u zaštiti novina," str. 3.
} 
novinskih zbirki, koji je prvenstveno usmjeren na povećanje dostupnosti novinskih sadržaja, uzimajući u obzir potrebe korisnika. ${ }^{41}$

Izradu nacionalnih elektroničkih sustava možemo podržati onim što korisnici stvarno žele - to je moguće postići samo identifikacijom korisnika i potencijalnih korisnika, odnosno istraživanjem ponašanja korisnika koji traže informacije, učenjem od njih. Ponuda gradiva, posebice novinskih sadržaja, u obliku prikladnom za korisnika adekvatan je odgovor na istraživačke potrebe, dokaz da ne radimo ad hoc. ${ }^{42}$

Posljednjih dvadeset godina, kako je digitalizacija postupno prelazila $s$ eksperimentalne i povremene aktivnosti na onu koja je strukturalna i kontinuirana, projekti modeliranja digitalnih novinskih zbirki postali su sve brojniji. Prema bazi podataka International Coalition on Newspapers (ICON), koja pruža informacije o svim započetim i realiziranim projektima digitalizacije novinskih sadržaja u svijetu, do 2015. godine realizirano je 8 internacionalnih i 567 nacionalnih projekata digitalizacije novinskih zbirki i kompleta novina u okviru 75 zemalja. ${ }^{43}$

Na području bivše SFRJ projekte digitalizacije novina i časopisa uspješno su realizirale pojedine kulturne ustanove i specijalizirane tvrtke za digitalizaciju iz Bosne i Hercegovine, Hrvatske, Slovenije i Srbije, no treba napomenuti da su u istima pretežito obuhvaćene novine i časopisi objavljeni do 1945 . godine te novine tiskane nakon 1945., čiji novinski članci nisu arhivirani u Vjesnikovoj novinskoj dokumentaciji.

\footnotetext{
41 Maja Šojat-Bikić, "Baštinski pristup digitalizaciji povijesnih novina: od povijesnih novina do digitalne zbirke sadržaja," Medijska istraživanja 12, br. 2 (2006): str. 23.

42 Pavelin, Odnosi s javnošću u funkciji potpore arhivskom menadžmentu i menadžmentu dogadanja (Zagreb: Alinea, 2017), str. 403.

43 "International Coalition on Newspapers (ICON)," (Center for Research Libraries), pristupljeno 29. travnja 2020., http://icon.crl.edu/digitization.php.
} 
Tablica 6. Pregled mrežno dostupnih periodičkih publikacija (novina i časopisa) tiskanih u razdoblju od 1964. do 1990. na području Bosne i Hercegovine, ${ }^{44}$ Crne Gore, Sjeverne Makedonije, Slovenije $e^{45}$ i Srbije ${ }^{46}$ te u razdoblju od 1964. do 2006. na području Hrvatske. ${ }^{47}$

\begin{tabular}{|c|c|c|}
\hline Država & Periodička publikacija & Razdoblje \\
\hline \multirow{2}{*}{ Bosna i Hercegovina } & Sineast & 1967.-1990. \\
\hline & Tribunia & $1975 .-1985$. \\
\hline Crna Gora & - & - \\
\hline \multirow{15}{*}{ Hrvatska } & Acta Medicorum & $1993 . / 2006$. \\
\hline & Bilokalnik & 1964.-2003. \\
\hline & Bjelovarski list & $1964 .-1987$. \\
\hline & Časopis Saveza radioamatera Jugoslavije & 1964.-1993. \\
\hline & Dijete, škola, obitelj & 1999.-2006. \\
\hline & Dijete, vrtić, obitelj & $1995 .-2006$. \\
\hline & Đurđevački vjesnik & $1964 . / 1969$. \\
\hline & Elektrotehničar & 1964.-1987. \\
\hline & Glas mladih Istre & 1976.-1979. \\
\hline & Glas Podravine & 1964.-2006. \\
\hline & $\begin{array}{l}\text { Hrašće: časopis za književnost, umjetnost, } \\
\text { kulturu i povijest }\end{array}$ & 1996.-2006. \\
\hline & Istarski borac & 1964.-1974. \\
\hline & Koprivničke novine & 1995., 1996. \\
\hline & Koprivnički magnum & 1990., 1991. \\
\hline & $\begin{array}{l}\text { Liječnički vjesnik: glasilo Hrvatskog liječničkog } \\
\text { zbora }\end{array}$ & 1964.-1974. \\
\hline
\end{tabular}

${ }_{44}$ Na temelju: "Publikacije," (Infobiro Digitalni arhiv), pristupljeno 10. svibnja 2020., http://www. infobiro.ba/publikacije.

45 “Digitalna knjižnica Slovenije," (Narodna in univerzitetna knjižnica Slovenije), pristupljeno 20. svibnja 2020., http://www.dlib.si/Publications.aspx.

46 Na temelju: "Pretražive digitalizovane istorijske novine," (Univerzitetska biblioteka Svetozar Marković), pristupljeno 23. svibnja 2020., http://www.unilib.rs/istorijske-novine/pregled; "Digitalna biblioteka grada Beograda," (Biblioteka grada Beograda), pristupljeno 23. svibnja 2020., https://digitalna. bgb.rs/en/jsp/RcWebBrowse.jsp; "Digitalna biblioteka Matice srpske," (Matica srpska), pristupljeno 20. svibnja 2020., http://digital.bms.rs/ebiblioteka/collections/; "Digitalna Narodna biblioteka Srbije," (Narodna biblioteka Srbije), pristupljeno 20. svibnja 2020., https://digitalna.nb.rs/sf/NBS/novine; "Politikin zabavnik," (Politikin zabavnik), pristupljeno 20. svibnja 2020., http://politikin-zabavnik.rs/ public/magazini.

47 "Metelwin digitalna knjižnica," (Fakultet organizacije i informatike, Varaždin), pristupljeno 15. svibnja 2020., http://library.foi.hr/lib/knjiga.php?sqlx=N00003\&sqlid=1\&C=3\&H=\&vrsta=\&grupa= \&lang=hr. 


\begin{tabular}{|c|c|c|}
\hline Država & Periodička publikacija & Razdoblje \\
\hline \multirow{20}{*}{ Hrvatska } & $\begin{array}{l}\text { LOK: list općinske konferencije saveza } \\
\text { socijalističke omladine Hrvatske Koprivnica }\end{array}$ & 1979.-1989. \\
\hline & Meteorološki i hidrološki bilten & 1987.-2006. \\
\hline & Novi magnum & 1991. \\
\hline & $\begin{array}{l}\text { Osvit: časopis omladine Gimnazije } \\
\text { "Ive Marinkovića" u Koprivnici }\end{array}$ & 1964.-1966. \\
\hline & Plitvički vjesnik & 1973./1997. \\
\hline & Podravac & 1991., 1992. \\
\hline & Podravski tjednik & 1992. \\
\hline & Priroda & 1964.-2004. \\
\hline & Ruke: književni prilog Glasa Podravine & 1977.-1979. \\
\hline & Scientia Podravina & 1989.-2006. \\
\hline & $\begin{array}{l}\text { Susreti: smotra suvremenih prosudbi mladih } \\
\text { Podravine }\end{array}$ & 1971. \\
\hline & $\begin{array}{l}\text { Sportske informacije: službeno glasilo SIZ } \\
\text { fizičke kulture i Saveza za fizičku kulturu } \\
\text { općine Varaždin }\end{array}$ & 1976.-1981. \\
\hline & $\begin{array}{l}\text { Svezak: časopis Društva knjižničara Bilogore, } \\
\text { Podravine i Kalničkog prigorja }\end{array}$ & 1999.-2006. \\
\hline & Varteksov vjesnik & 1955.-1966. \\
\hline & Varaždinske vijesti & 1964.-1997. \\
\hline & $\begin{array}{l}\text { Vijesti iz Hidrometeorološke službe NR } \\
\text { Hrvatske }\end{array}$ & 1964.-1991. \\
\hline & Vijesti Pomorske meteorološke službe & 1964.-1986. \\
\hline & Vinkovački list & 1964.-2006. \\
\hline & Virovitički list & 1993.-2006. \\
\hline & $\begin{array}{l}\text { Zdravstveni vjesnik: glasilo radnika } \\
\text { Medicinskog centra Varaždin } \\
\end{array}$ & 1976./1987. \\
\hline Sjeverna Makedonija & - & - \\
\hline \multirow{7}{*}{ Slovenija } & Almira & 1974./1988. \\
\hline & Aluminij & 1964.-1990. \\
\hline & Avstralski Slovenec & 1981.-1983. \\
\hline & Beseda Slovenske skupnosti & $1970 . / 1975$. \\
\hline & Beti & 1969.-1972. \\
\hline & Bohor žari & $1979 . / 1990$. \\
\hline & Celjski tednik & 1964.-1968. \\
\hline
\end{tabular}




\begin{tabular}{|c|c|c|}
\hline Država & Periodička publikacija & Razdoblje \\
\hline \multirow{34}{*}{ Slovenija } & Celjski zbornik & $1964 . / 1990$. \\
\hline & Cinkarnar & 1964.-1990. \\
\hline & Cvetje in zelenje & $1972 .-1973$. \\
\hline & Čevljar & 1971.-1990. \\
\hline & Delegatski obveščevalec & $1982 . / 1987$. \\
\hline & Delo, življenje & 1964.-1990. \\
\hline & Delo & 1964.-1990. \\
\hline & Dogovori & 1973.-1990. \\
\hline & Dolenjski list & 1964.-1990. \\
\hline & Dolenjski razgledi & 1968./1990. \\
\hline & Dolenjski zbornik & 1985./1990. \\
\hline & Domače novice & 1964./1990. \\
\hline & Draga & 1976./1990. \\
\hline & Emajlirec & 1964.-1990. \\
\hline & Glas & $1964 .-1984$. \\
\hline & Glasilo delovnega kolektiva LIP Bled & 1971.-1990. \\
\hline & Glasilo Elmont & 1985.-1990. \\
\hline & Gledališki list & $1964 .-1965$. \\
\hline & Gorenjski glas & $1985 .-1990$. \\
\hline & Gorenjski knjižničar & 1964. \\
\hline & Hortikulturni bilten & 1971. \\
\hline & Idrijski razgledi & 1964./1990. \\
\hline & Informativni fužinar & 1964.-1990. \\
\hline & Iskra & $1964 .-1972$. \\
\hline & Iskre & 1969.-1990. \\
\hline & Izvestje Gimnazije Dušana Kvedra v Ptuju & $1969 .-1979$. \\
\hline & Izvir & 1968./1990. \\
\hline & Javna tribina & 1964.-1990. \\
\hline & Jeklo in ljudje & 1964./1985. \\
\hline & Kamniški občan & 1964.-1990. \\
\hline & Kamniški zbornik & 1965.-1969. \\
\hline & Kaplje & 1966.-1972. \\
\hline & \begin{tabular}{|l} 
Katoliški glas \\
\end{tabular} & 1964.-1990. \\
\hline & Klubske novice & 1982./1987. \\
\hline
\end{tabular}




\begin{tabular}{|c|c|c|}
\hline Država & Periodička publikacija & Razdoblje \\
\hline \multirow{32}{*}{ Slovenija } & Koledar - Goriška mohorjeva družba & 1964.-1990. \\
\hline & Komunist & 1964.-1990. \\
\hline & Koncertni list & 1964.-1979. \\
\hline & Koroški fužinar & 1964.-1990. \\
\hline & Krajan & 1980.-1986. \\
\hline & Krajevni informator & 1988.-1989. \\
\hline & Kurent & 1973./1990. \\
\hline & Labod & 1966./1990. \\
\hline & $\begin{array}{l}\text { Letno poročilo Narodne in univerzitetne } \\
\text { knjižnice v Ljubljani }\end{array}$ & 1970./1990. \\
\hline & $\begin{array}{l}\text { Letopis Slovenske akademije znanosti in } \\
\text { umetnosti }\end{array}$ & 1964.-1990. \\
\hline & Listi & 1970./1987. \\
\hline & Logaške novice & 1970.-1990. \\
\hline & Lojzetov konjiček & 1987.-1990. \\
\hline & Loški razgledi & 1964.-1990. \\
\hline & Luški glasnik & 1989.-1990. \\
\hline & Ljubljanski dnevnik & 1965. \\
\hline & Meddobje & 1964./1990. \\
\hline & Mehanotehnika & 1977.-1983. \\
\hline & Misli & 1964.-1990. \\
\hline & Mladi planinec & 1977.-1990. \\
\hline & Mladika & 1964.-1990. \\
\hline & Mohorjev koledar & 1973.-1990. \\
\hline & MOST & 1964./1988. \\
\hline & $\mathrm{Na}$ trgu & 1987. \\
\hline & Naš čas & 1973.-1990. \\
\hline & Naš časopis & 1973.-1990. \\
\hline & Naš glas & 1964.-1990. \\
\hline & Naša skupnost & 1971.-1990. \\
\hline & Naša vez & 1981. \\
\hline & Naše delo & $1967 . / 1982$. \\
\hline & Naše novine & 1978.-1980. \\
\hline & Novi list & 1964.-1990. \\
\hline
\end{tabular}




\begin{tabular}{|c|c|c|}
\hline Država & Periodička publikacija & Razdoblje \\
\hline \multirow{34}{*}{ Slovenija } & Novi matajur & 1974.-1990. \\
\hline & Novi tednik & 1964.-1990. \\
\hline & Novice: Bulletin & $1978 . / 1990$. \\
\hline & Novoteks & 1973./1988. \\
\hline & Občinski poročevalec: glasilo občine Domžale & 1964.-1990. \\
\hline & Obvestila & 1964.-1973. \\
\hline & Obvestila Republike matične službe & 1968./1990. \\
\hline & Odsev & $1977 . / 1982$. \\
\hline & Odsevanja & 1979.-1990. \\
\hline & Panorama & 1964.-1965. \\
\hline & Pest & 1987. \\
\hline & Petkov teden & 1986.-1990. \\
\hline & Petrol & 1964.-1990. \\
\hline & Planinski vestnik & 1964.-1990. \\
\hline & Primorski dnevnik & 1964./1988. \\
\hline & Ptujski zbornik & 1969./1985. \\
\hline & Rast & 1982.-1990. \\
\hline & Rezultati raziskovanj & 1976.-1990. \\
\hline & Rudar & 1964./1990. \\
\hline & Savinjske novice & 1969.-1990. \\
\hline & Savinjski občan & 1978.-1990. \\
\hline & Savinjski zbornik & 1965./1988. \\
\hline & Skupščinski Dolenjski list & 1967.-1990. \\
\hline & Slovenska država & 1964.-1990. \\
\hline & Slovenski vestnik & 1964.-1990. \\
\hline & Smučina Alan & 1964.-1990. \\
\hline & Snežniški razgledi & 1967. \\
\hline & Snovanja & 1967.-1979. \\
\hline & Sodobnost & 1964.-1990. \\
\hline & Statističko gradivo SR Slovenije & $1964 . / 1978$ \\
\hline & Steklar & $1965 . / 1990$. \\
\hline & Stezice & 1964./1990. \\
\hline & Svobodna Slovenija & 1964./1989. \\
\hline & Svobodni razgovori & 1984. \\
\hline
\end{tabular}




\begin{tabular}{|c|c|c|}
\hline Država & Periodička publikacija & Razdoblje \\
\hline \multirow{25}{*}{ Slovenija } & Šaleški rudar & $1965 .-1972$. \\
\hline & Štolski železar & 1964.-1990. \\
\hline & Tedenska tribuna & 1964.-1973. \\
\hline & Tednik (Ptuj) & 1964.-1990. \\
\hline & Tekstilec & 1964.-1987. \\
\hline & Tim & 1964./1990. \\
\hline & Tovariš & 1964.-1973. \\
\hline & Tribuna (Ljubljana) & $1964 . / 1990$. \\
\hline & Triglav & $1969 . / 1979$. \\
\hline & Trinkov koledar & $1964 .-1985$. \\
\hline & Tržiški tekstilec & $1964 . / 1990$. \\
\hline & $\begin{array}{l}\text { Uradne objave občin Ilirska Bistrica, Izda, } \\
\text { Koper, Piran, Postojna in Sežana }\end{array}$ & 1967./1990. \\
\hline & Uradni glasnik & 1965.-1966. \\
\hline & Uradni glasnik okraja Koper & $1963 .-1965$. \\
\hline & $\begin{array}{l}\text { Uradni vestnik (občina Dolenjske, Domžale, } \\
\text { Gorenjske, Kamnik i Zasavja) }\end{array}$ & 1964./1990. \\
\hline & Utrip & 1978.-1990. \\
\hline & Veriga & $1979 . / 1987$. \\
\hline & Vezilo & $1972 . / 1990$. \\
\hline & Viharnik & 1973.-1990. \\
\hline & Vipavski glas & 1985.-1990. \\
\hline & Vrednote & 1968. \\
\hline & Zbor občanov & $1970 . / 1990$. \\
\hline & Zbornik Svobodne Slovenije & $1964 . / 1975$. \\
\hline & Zvon Marije Pomočnice na Rakovniku & $1969 .-1972$. \\
\hline & Žirovski občasnik & $1980 . / 1990$ \\
\hline \multirow{7}{*}{ Srbija } & Anali Pravnog fakulteta u Beogradu & $1964 . / 1975$. \\
\hline & Belocrkvanske novine & 1976.-1990. \\
\hline & Bilten Bitefa & 1967.-1990. \\
\hline & Bilteni mladih istraživača & 1969./1981. \\
\hline & Danas & 1964.-1970. \\
\hline & Demokratija danas & 1989. \\
\hline & Đuboks magazin & 1966.-1967. \\
\hline
\end{tabular}




\begin{tabular}{|c|c|c|}
\hline Država & Periodička publikacija & Razdoblje \\
\hline \multirow{33}{*}{ Srbija } & Ekološke novine & 1981. \\
\hline & Eureka & 1974. \\
\hline & Gledišta & 1968. \\
\hline & Godišnjak Biblioteke Matice srpske & 1977./1990. \\
\hline & Istraživač & 1971., 1976 \\
\hline & $\begin{array}{l}\text { Istraživačke novine - list OIA “Tokovi SKOJ-a } \\
\text { 1979.” }\end{array}$ & 1980. \\
\hline & Jazz & 1990. \\
\hline & Komunistička iskra & 1990. \\
\hline & Kultura istoka & 1984.-1990. \\
\hline & Lazarevac: privredno-turistički vodič & 1989. \\
\hline & Letovanje pionira & 1965. \\
\hline & List kluba istraživača Azbukovica & $1975 .-1976$. \\
\hline & List mladih istraživača Srbije & 1982.-1989. \\
\hline & Mali neven & 1968. \\
\hline & Meteor & 1977. \\
\hline & Mladi istraživači (akcija i organizacija) & 1982. \\
\hline & Nada & 1976. \\
\hline & Narodna pravda & 1990. \\
\hline & OIA Brestovac & 1980. \\
\hline & Osnovac & 1975. \\
\hline & Otadžbina & 1990. \\
\hline & Pčelar & $1964 .-1990$ \\
\hline & Penzionerski petak & 1973. \\
\hline & Plan zimovanja pionira & 1965. \\
\hline & Poezija & 1969. \\
\hline & Polet & 1975. \\
\hline & Politika - omladinska istraživačka sekcija & 1978. \\
\hline & Politikin zabavnik & 1964.-1990. \\
\hline & Prvi koraci & 1975. \\
\hline & Rad Matice srpske & 1971.-1990. \\
\hline & Ritam & 1989.-1990. \\
\hline & RTS - posebna izdanja & 1979./1988. \\
\hline & RTV - teorija i praksa & 1975.-1990. \\
\hline
\end{tabular}




\begin{tabular}{|l|l|l|}
\hline Država & Periodička publikacija & Razdoblje \\
\hline \multirow{5}{*}{ Srbija } & Selo & 1986. \\
\cline { 2 - 3 } & Sorabi & 1982. \\
\cline { 2 - 3 } & Student & 1968. \\
\cline { 2 - 3 } & Vasiona & 1969. \\
\cline { 2 - 3 } & Velika Srbija & 1990. \\
\hline & Vesti iz biblioteke Matice srpske & $1987 .-1990$. \\
\hline Zadruga & 1965. \\
\hline & Zbornici radova mladih istraživača & $1971 . / 1988$. \\
\cline { 2 - 3 } & Zrak & 1975. \\
\hline & Žena & 1986. \\
\hline & 150 godina škole "Jovan Popovićc" & 1974. \\
\hline
\end{tabular}

Pregledom mrežno dostupnih novina i časopisa tiskanih u razdoblju od 1964. do 1990. na području bivše SFRJ te od 1991. do 2006. godine na području Republike Hrvatske moguće je zaključiti kako je Slovenija učinila mrežno dostupnim najveću količinu novina i časopisa iz socijalističkoga razdoblja, a da ju slijede Srbija i Hrvatska. Od mrežno dostupnih novina i časopisa najveći udio čini stručna periodika i periodika lokalnoga karaktera. Gotovo su svi novinski sadržaji, osim iz Bosne i Hercegovine, besplatni za korisnike.

Primarni razlog zbog kojega imatelji digitaliziranih novinskih zbirki novijega datuma ne nude mrežni pristup istima autorska su prava. Novine sadržavaju brojne i raznovrsne priloge, pa i fotografije, koji su često autorska djela. Ako je autor novinskoga članka poznat, prilog je zaštićen za njegova života ili ako od njegove smrti nije proteklo 70 godina. U slučaju da novinski prilozi nisu potpisani, obično su nositelji prava na članke novinske kuće. U Republici Hrvatskoj nužno je prije same provedbe postupka digitalizacije i javne objave obratiti se neposredno nositelju autorskoga prava za dopuštenje, koji ujedno ima pravo na naknadu. Iznimno je ustanovama (arhivi i knjižnice) dopušteno reproduciranje zaštićenoga gradiva na bilo koju podlogu, što znači da je uz mikrofilmiranje dopušteno i skeniranje te digitaliziranje, uz uvjet da je digitalizirano gradivo pohranjeno samo na jednom poslužniku. Svrha navedenoga izuzeća u reprodukciji autorskih djela u ustanovama Republike Hrvatske zaštita je rijetkoga i oštećenoga gradiva. ${ }^{48}$

48 Aleksandra Horvat i Daniela Živković, Knjižnice i autorsko pravo (Zagreb: Hrvatska sveučilišna naklada, 2013). str. 52, 97-98. 
Prvi pokušaj prijenosa Vjesnikove novinske dokumentacije iz konvencionalnoga oblika u digitalni započeo je 2004. godine u izdavačkoj kući Vjesnik, no već je sljedeće godine zaustavljen. Naredni pokušaj digitalizacije zbirke prvotni je razlog zašto je ista prebačena u Hrvatsku izvještajnu novinsku agenciju 2006. godine. Naime, država je osigurala 9 milijuna kuna s ciljem da se cjelokupna zbirka digitalizira i poveže $s$ postojećom Hininom bazom podataka EVA. ${ }^{49}$ Budući da se kroz pet godina provedbe projekta zbirka digitalizirala tek manjim dijelom, a da su utrošena znatna financijska sredstva, Ministarstvo kulture 2013. godine odlučilo je zaustaviti projekt digitalizacije te ju predati novomu imatelju - Hrvatskomu državnomu arhivu. ${ }^{50}$ U razdoblju od 2014. do 2016. godine Hrvatski državni arhiv nastavio je ulagati u digitalizaciju zbirke kroz trogodišnji program digitalizacije arhivskoga gradiva, u okviru kojega je digitalizirano oko 200.000 novinskih članaka. ${ }^{51}$

Dosadašnje iskustvo digitalizacije Vjesnikove novinske dokumentacije pokazalo je da je prijenos tematski organiziranih novinskih članaka iz konvencionalnoga oblika u digitalni izrazito složen postupak koji zahtijeva izdašno ulaganje financijskih resursa i vremena. Tomu je osobito pridonijelo različito formatiranje novinskih članaka prilikom obrade zbirke, koje u postupku digitalizacije, uspoređujući s digitalizacijom kompleta novina standardnoga formata, podrazumijeva složeniju računalnu obradu. $S$ druge strane, u skladu sa svjetskim trendovima, većina država s prostora bivše SFRJ uspješno su digitalizirale i učinile mrežno dostupnim pretežni dio svojih starih novina i časopisa ${ }^{52}$ u okviru nacionalnih i internacionalnih projekata digitalizacije. Iako postojeće mrežno dostupne novine i časopisi iz socijalističkoga razdoblja uglavnom ne sadrže dnevnu novinsku produkciju, koja čini okosnicu Vjesnikove novinske dokumentacije, neupitna je njihova digitalizacija i mrežna dostupnost u budućnosti, poglavito nakon proteka roka zaštićenosti autorskim pravom. Na temelju istraživanja u ovom radu došlo se do spoznaje da je broj korisničkih zahtjeva Vjesnikove novinske dokumentacije u razdoblju od 1. lipnja 2013. do 31. prosinca 2019. podosta bitan. Međutim, prethodno spominjani problemi nedostatka sustavnijega istraživanja profila korisnika arhiva i s time povezane obrade gradiva za njihove potrebe te manjka dostatnih financijskih sredstava za digitalizaciju toga gradiva upućuju na to da u skoroj budućnosti ne možemo težiti cjelovitoj digitalizaciji. Preostaje barem, s ciljem zaštite izvornika, provesti digitalizaciju najugroženijih tematskih cjelina.

\footnotetext{
49 Cjelokupan postupak pokušaja digitalizacije Vjesnikove novinske dokumentacije u okviru izdavačke kuće Vjesnik i Hine opisan je u stručnom članku Lane Žaja, "Digitalizacija i organizacija znanja baze podataka Vjesnikove novinske dokumentacije," Arhivska praksa 1, br. 21 (2018): str. 212-231.

50 “Izvješće o radu Upravnog vijeća Hine za 2013.," str. 4.

51 "Izvještaj o radu u 2016. godini” (Hrvatski državni arhiv).

52 Izraz stare novine i časopisi najčešće se odnosi na razdoblje od početka njihova objavljivanja do sredine 20. stoljeća. Silvio Lebinac, "Priprema starih novina za mikrofilmiranje i digitalizaciju," Vjesnik bibliotekara Hrvatske 55, br. 2 (2012): str. 97.
} 


\section{Zaključak}

Tijekom pedesetogodišnjega razdoblja u kojem je nastajala, Vjesnikova novinska dokumentacija bila je jedina javna novinska dokumentacija u Hrvatskoj kojom su se prvenstveno služili novinari svih medija, kao podlogom u stvaranju novoga novinarskoga sadržaja. Njezina osobita vrijednost ogleda se u činjenici da je nastala u izdavačkoj kući Vjesnik, koja ima bitno mjesto u povijesti informativne djelatnosti u Hrvatskoj u drugoj polovici 20. stoljeća i razdoblju stvaranja samostalne i suverene Republike Hrvatske.

Suvremeni tehnološki razvoj i masovna uporaba Interneta dovela je do pojave mrežnih medija, zbog čega je Vjesnikova dokumentacijska zbirka izgubila svoju prvotnu ulogu javnoga servisa novinarske struke, ali je istovremeno postala nacionalno i multikulturno pisano nasljeđe. Upravo zbog činjenice da sadrži cjelokupnu dnevnu novinsku produkciju bivše države (SFRJ) od 1964. godine i Republike Hrvatske do 2006., danas ju možemo smatrati relevantnim izvorom informacija za znanstvena i stručna istraživanja. Tomu pridonosi i istraživački postupak ovoga rada, koji je potvrdio da se Vjesnikova zbirka, otkako je premještena u Hrvatski državni arhiv, na temelju relativno dobro strukturiranoga popisa i u odnosu na ostalo imateljevo gradivo, istražuje u bitnoj mjeri.

Iako cjelovita zaštita i mrežna dostupnost Vjesnikove novinske dokumentacije ovisi o mogućnostima njezine digitalizacije, uzimajući u obzir dosadašnje iskustvo, koje je pokazalo da je prijenos tematski organiziranih novinskih članaka iz konvencionalnoga oblika u digitalni izrazito kompleksan postupak, koji zahtijeva izdašno ulaganje financijskih resursa i vremena, sve brojnije korisničko modeliranje mrežno dostupnih novina i časopisa koji vremenski i prostorno odgovaraju nastanku predmetne zbirke, a omogućuju pretragu sadržaja prema ključnim riječima, te evidentan problem nedostatka sustavnijega istraživanja profila korisnika arhiva is time povezane obrade gradiva za njihove potrebe, moguće je zaključiti da se postupci pretvorbe Vjesnikove novinske zbirke u digitalni oblik trebaju provoditi djelomično, isključivo s ciljem zaštite kulturnoga nasljeđa. 


\section{POPIS IZVORA}

\section{Arhivsko gradivo}

\section{Državni arhiv u Zagrebu}

Odjel za zaštitu arhivskog gradiva izvan arhiva.

Pismohrana.

\section{Hrvatski državni arhiv}

HR-HDA-2031. Vjesnik.

Korisnička služba i čitaonica.

Odsjek za arhivsko gradivo od 1991.

Odsjek za gradivo izvan Arhiva.

Pismohrana.

\section{Službena glasila i tisak}

Narodne novine (Zagreb), 1990, 2013.

\section{Literatura}

Balun, Kristina. "Zlatni rudnik novinskih isječaka uskoro dostupan i u digitalnom obliku?" Global: Novine za studentska i drustvena pitanja, kulturu i sport 1, br. 1 (svibanj 2014.): str. 4-5.

Brautović, Mato. Online novinarstvo. Zagreb: Školska knjiga, 2011.

Bukvić, Nenad. "Vjesnikova novinska dokumentacija." Courage connecting collections. Pristupljeno 30. siječnja 2020. http://culturalopposition.eu/ registry/?uri=http://courage.btk.mta.hu/courage/individual/n14713.

"Digitalna biblioteka grada Beograda." Biblioteka grada Beograda. Pristupljeno 23. svibnja 2020. https://digitalna.bgb.rs/en/jsp/RcWebBrowse.jsp.

"Digitalna biblioteka Matice srpske." Matica srpska. Pristupljeno 20. svibnja 2020. http://digital.bms.rs/ebiblioteka/collections/.

"Digitalna knjižnica Slovenije." Narodna in univerzitetna knjižnica Slovenije. Pristupljeno 20. svibnja 2020. http://www.dlib.si/Publications.aspx.

"Digitalna Narodna biblioteka Srbije." Narodna biblioteka Srbije. Pristupljeno 20. svibnja 2020. https://digitalna.nb.rs/sf/NBS/novine. 
“Godišnje izvješće za 2006.” Republika Hrvatska, Ministarstvo kulture, 2007. Pristupljeno 18. veljače 2020. https://www.min-kulture.hr/userdocsimages/dokumenti/Izvjestaj\%20MK\%20za\%20CD.pdf.

Hodonj, Željko, Lana Žaja. "Mediji i demokracija, baza podataka, dubinsko pretraživanje, izravni pristup - digitalizacija novinskog arhiva i organizacija znanja u bazu podataka." U INFuture2007: Digital information and Heritage, ur. Sanja Seljan i Hrvoje Stančić, str. 227-242. Zagreb: Filozofski fakultet Sveučilišta u Zagrebu, 2007.

Horvat, Aleksandra, Daniela Živković. Knjižnice i autorsko pravo. Zagreb: Hrvatska sveučilišna naklada, 2013.

"International Coalition on Newspapers (ICON)." Center for Research Libraries. Pristupljeno 29. travnja 2020. http://icon.crl.edu/digitization.php.

“Izvješće o izvršenju programa rada Hrvatskog državnog arhiva za 2019. godinu." Hrvatski državni arhiv, 2020. Pristupljeno 25. svibnja 2020. http:// www.arhiv.hr/Portals/0/Dokumenti/Planovi\%20i\%20izvje\%C5\%A1\%C4\%87a/ Izvje $\%$ C $5 \%$ A $1 \%$ C $4 \% 87 \mathrm{e} \% 20$ o $\% 20$ izvr $\%$ C $5 \%$ A 1 enju $\% 20$ programa $\% 20$ rada $\% 20$ Hrvatskog\%20dr\%C5\%BEavnog\%20arhiva\%20za\%202019.g.. pdf?ver=2020-03-09-122922-897.

"Izvješće o obavljenoj reviziji pretvorbe i privatizacije društvenog poduzeća Vjesnik.” Republika Hrvatska Državni ured za reviziju, 2003. Pristupljeno 10. veljače 2019. http://www.revizija.hr/izvjesca/2007/revizije-pretvorbe-i-privatizacije/850-vjesnik-zagreb.pdf.

“Izvješće o radu u 2013. godini." Hrvatski državni arhiv, 2013. Pristupljeno 25. svibnja 2020. http://www.arhiv.hr/Portals/0/Dokumenti/Planovi\%20 i\%20izvje\%C5\%A1\%C4\%87a/Izvje\%C5\%A1\%C4\%87e\%20o\%20radu\%20 HDA\%20u\%202013.\%20godini.pdf?ver=2017-03-23-092024-000.

“Izvješće o radu u 2014. godini." Hrvatski državni arhiv, 2015. Pristupljeno 25. svibnja 2020. http://www.arhiv.hr/Portals/0/Dokumenti/Planovi\%20 i\%20izvje\%C5\%A1\%C4\%87a/Izvje\%C5\%A1\%C4\%87e\%20o\%20radu\%20 HDA\%20u\%202014.\%20godini.pdf?ver=2017-03-23-092022-000.

“Izvješće o radu u 2015. godini." Hrvatski državni arhiv, 2016. Pristupljeno 25. svibnja 2020. http://www.arhiv.hr/Portals/0/Dokumenti/Planovi\%20 i\%20izvje\%C $5 \%$ A $1 \%$ C $4 \% 87$ a/Izvje $\% C 5 \% A 1 \% C 4 \% 87 \mathrm{e} \% 20$ o\%20radu\%20 HDA\%20u\%202015.\%20godini.pdf?ver=2017-03-23-092021-967.

"Izvješće o radu Upravnog vijeća Hine za 2013." HINA, Upravno vijeće, 2014. Pristupljeno 20. veljače 2020. https://www.hina.hr/Content/Static/Uv_ 2013.pdf.

“Izvještaj o radu u 2016. godini." Hrvatski državni arhiv, 2017. Pristupljeno 25. svibnja 2020. http://www.arhiv.hr/Portals/0/Dokumenti/Planovi\%20 
i\%20izvje\%C5\%A1\%C4\%87a/Izvje\%C5\%A1\%C4\%87e\%20o\%20radu\%20 HDA\%20u\%202016.\%20godini.pdf?ver=2017-03-23-092024-000.

"Izvještaj o radu u 2017. godini." Hrvatski državni arhiv, 2018. Pristupljeno 25. svibnja 2020. http://www.arhiv.hr/Portals/0/Dokumenti/Planovi\%20 i\%20izvje\%C5\%A1\%C4\%87a/Izvje\%C5\%A1\%C4\%87e\%20o\%20radu\%20 HDA\%20u\%202017.\%20godini.pdf?ver=2018-03-12-130526-847.

"Izvještaj o radu u 2018. godini." Hrvatski državni arhiv, 2019. Pristupljeno 25. svibnja 2020. http://www.arhiv.hr/Portals/0/Dokumenti/Planovi\%20 i\% 20 izvje \% C5\%A 1\%C4\% 87a/Izvje\%C5\%A 1 taj\%20o\%20 radu \% 20 HDA\%20za\%202018.godinu.pdf?ver=2020-02-05-123337-490.

Krtalić, Maja. "Pristupi, metode i dostignuća u zaštiti novina." Vjesnik bibliotekara Hrvatske 51 (2008): str. 1-18.

Laić, Igor. "Novinska arhiva skrivena u Kerestincu." H-Alter, 25. lipnja 2012. Pristupljeno 20. veljače 2020. https://www.h-alter.org/vijesti/novinskaarhiva-skrivena-u-kerestincu.

Lebinac, Silvio. "Priprema starih novina za mikrofilmiranje i digitalizaciju." Vjesnik bibliotekara Hrvatske 55, br. 2 (2012): str. 95-110.

Lemić, Vlatka. "Vjesnikova novinska dokumentacija u Hrvatskom državnom arhivu kao izvor za istraživanje povijesti Istre." Vjesnik istarskog arhiva 25 (2018): str. 19-35.

"Metelwin digitalna knjižnica." (Metelgrad). Fakultet organizacije i informatike, Varaždin. Pristupljeno 15. svibnja 2020. http://library.foi.hr/metelgrad/ index.php?page $=$ digi 2 . keting, 2005.

Novak, Božidar. Hrvatsko novinarstvo u 20. stoljeću. Zagreb: Golden mar-

Pavelin, Goran. Informacijsko-komunikacijska podloga strateškog planiranja arhiva. Zadar: Državni arhiv u Zadru, 2019.

Pavelin, Goran. Odnosi s javnošću u funkciji potpore arbivskom menadžmentu i menadžmentu dogadanja. Zagreb: Alinea, 2017.

"Politikin zabavnik." Politikin zabavnik. Pristupljeno 20. svibnja 2020. http://politikin-zabavnik.rs/public/magazini.

"Popis Vjesnikove novinske dokumentacije." Hrvatski državni arhiv, 2013., str 2. Pristupljeno 4. ožujka 2020. http://arhinet.arhiv.hr/details.aspx?Item $\mathrm{Id}=2 \_6536$.

"Popis Vjesnikove novinske dokumentacije: Odsjek za arhivsko gradivo od 1991.” Hrvatski državni arhiv, 2019. 
"Pretražive digitalizovane istorijske novine." Univerzitetska biblioteka Svetozar Marković. Pristupljeno 23. svibnja 2020. http://www.unilib.rs/istorijske-novine/pregled.

"Prijavnica za korištenje arhivskog gradiva." Hrvatski državni arhiv, s. a. Pristupljeno 6. rujna 2020. http://zagreb.arhiv.hr/hr/koristenje/prijavnica.pdf.

“Publikacije." Infobiro Digitalni arhiv. Pristupljeno 10. svibnja 2020. http://www.infobiro.ba/publikacije.

Slijepčević, Vladimir. "Pet posljednjih godina." U Zbornik sjećanja: Vjesnik 1940-1990, ur. Milan Bekić, str. 221-249. Zagreb: NIŠPRO "Vjesnik", 1990.

"Strategija razvoja širokopojasnog pristupa u RH do 2008. godine." Republika Hrvatska, Ministarstvo mora, turizma, prometa i razvitka, 2006. Pristupljeno 13. veljače 2020. https://www.hakom.hr/userDocsImages/javnarasprava/rkazic/159/Strategija.broadbrandRH.pdf.

Šojat-Bikić, Maja. "Baštinski pristup digitalizaciji povijesnih novina: od povijesnih novina do digitalne zbirke sadržaja." Medijska istraživanja 12, br. 2 (2006): str. 19-40.

Žaja, Lana. "Digitalizacija i organizacija znanja baze podataka Vjesnikove novinske dokumentacije.” Arhivska praksa 1, br. 21 (2018): str. 212-231. 
Summary

\section{THE RELEVANCY OF VJESNIK'S NEWSPAPER DOCUMENTATION AS THE CULTURAL GOOD OF THE REPUBLIC OF CROATIA AND AS ARCHIVAL SOURCE}

The paper analyses the users' function of the newspaper collection created within "Vjesnik" publisher from 1964 to 2006. Based on the available references and sources, the introduction describes the creation, purpose and function of Vjesnik's newspaper documentation within "Vjesnik", its parent publisher. The introductory deliberation is also complemented with the outline of the past insights regarding the strategic planning of the processing, the protection procedures that had been carried out, as well as usage of Vjesnik's documental collection from its creation to the transfer to the Croatian State Archives. The paper then presents the results of the analysis of the accessibility and usage of Vjesnik's newspaper documentation from 1 June 2013 i.e. its transfer to the Croatian State Archives and its definition as a cultural good to 31 December 2019. To that extent, the analysis ascertains the considerable percentage of usage of Vjesnik's newspaper documentation when compared to other conventional archival records stored at the Croatian State Archives during the specified period (the average of 9,61\%). The relevancy of Vjesnik's newspaper documentation as an archival source for scientific and professional research was additionally researched by analysing the content of its thematic wholes and examining the congruities of the content within technical units with the structured list, on the sample of minimal $1 \%$ of technical units. Based on this analysis the following had been established: 1. The information from the collection's structural list (numbers of technical units, titles of thematic wholes and subunits) completely matches the actual condition of the collection. 2. The main drawback in individual thematic wholes concerns the repeated overlapping of keywords in various subunits and the omission of the content's description regarding individual technical units, which makes it difficult to identify and find newspaper articles within them. 3. The newspaper articles were almost in their entirety put in the corresponding wholes i.e. only within the thematic whole entitled "Judiciary and crime" it was noticed that, considering their subject matter, the minority of newspaper articles should have been put in the "Society/Healthcare/Welfare" thematic whole. 4. The high congruity percentage regarding the description of technical units' contents with newspaper articles' subject matter within them (arithmetic mean i.e. $\mathrm{x}=95,44 \%$ ) enables the efficient search of identified and contextually described newspaper articles within archival boxes. Based on acquired research results of user function of Vjesnik's newspaper documentation, the attempts so far to convert it to digital form and research of the newspapers and magazines available online from the territory of the Socialist Republic of Yugoslavia in the period from 1964 to 1990 and the territory of the Socialist Republic of Croatia from 1990 to 2006, the 
paper conclusively examines the necessity of its full digitisation and suggests guidelines for further procedures regarding the increase of its availability and protection.

Keywords: Vjesnik's newspaper documentation; Vjesnik publisher; usage; digitisation; newspaper collection; archival records 